\title{
New opabiniid diversifies the weirdest wonders of the euarthropod lower stem group
}

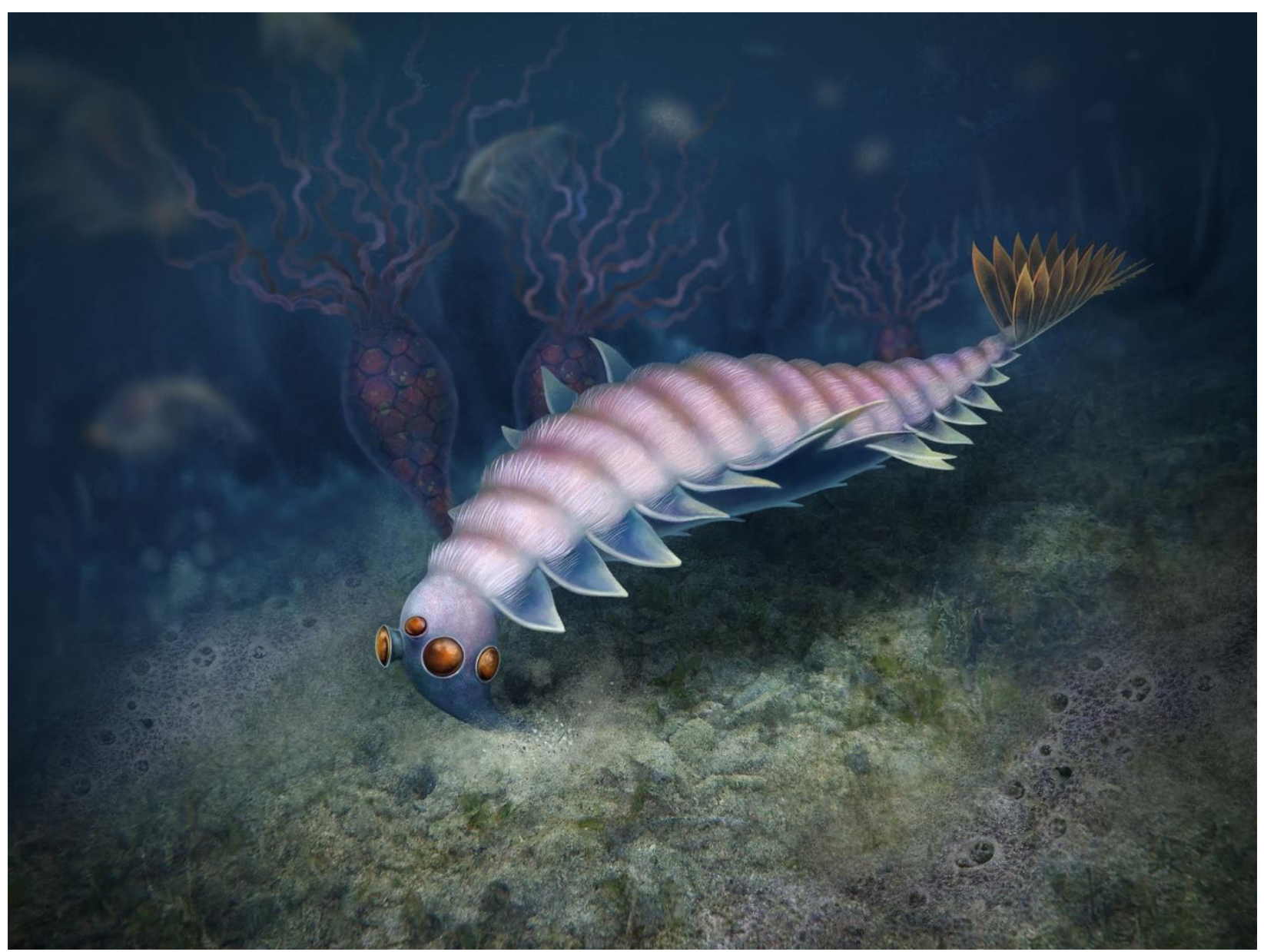

Cover image. Artistic reconstruction of the new opabiniid from the Wheeler Formation, Utah, USA (Cambrian: Drumian). Artwork by F. Anthony. 


\title{
New opabiniid diversifies the weirdest wonders of the euarthropod lower stem group
}

Stephen Pates ${ }^{1,2,4, *}$, Joanna M. Wolfe ${ }^{1,4, *}$, Rudy Lerosey-Aubril ${ }^{1}$, Allison C. Daley ${ }^{3}$, and Javier Ortega-Hernández ${ }^{1}$

${ }^{1}$ Museum of Comparative Zoology and Department of Organismic and Evolutionary Biology, Harvard University, 26 Oxford Street, Cambridge, MA 02138, USA

${ }^{2}$ Department of Zoology, University of Cambridge, Downing Street, Cambridge, CB2 3EJ, UK

${ }^{3}$ Institute of Earth Sciences, University of Lausanne, Géopolis, CH-1015 Lausanne, Switzerland

${ }^{4}$ These authors contributed equally: S. Pates, J.M. Wolfe

*E-mail: sp587@cam.ac.uk; jowolfe@g.harvard.edu

\begin{abstract}
Once considered 'weird wonders' of the Cambrian, the emblematic Burgess Shale animals Anomalocaris and Opabinia are now recognized as lower stem-group euarthropods.

Anomalocaris and its relatives (radiodonts) had a worldwide distribution and survived until at least the Devonian, whereas - despite intense study - Opabinia remains the only formally described opabiniid to date. Here we reinterpret a fossil from the Wheeler Formation of Utah as a new opabiniid, KUMIP 314087. By visualizing the sample of phylogenetic topologies in treespace, our results fortify support for the position of KUMIP 314087 beyond the nodal support traditionally applied. Our phylogenetic evidence expands opabiniids to multiple Cambrian Stages spanning approximately five million years. Our results underscore the power of treespace visualization for resolving imperfectly preserved fossils and expanding the known diversity and spatiotemporal ranges within the euarthropod lower stem group.
\end{abstract}

\section{Keywords}

Cambrian, Euarthropoda, Opabiniidae, phylogenetics, treespace, Wheeler Formation

\section{Additional note}

This work contains a new biological name. New names in preprints are not considered available by the ICZN. To avoid ambiguity, the new biological name is not included in this preprint, and the specimen number (KUMIP 314087) is used as a placeholder. 


\section{Introduction}

Euarthropods (e.g. chelicerates, myriapods, and pancrustaceans including insects) have conquered Earth's biosphere, comprising over $80 \%$ of living animal species (Santos, de Almeida and Fernandes, 2021). Indeed, Euarthropoda has been the most diverse animal phylum for over half a billion years, documented by prolific trace and body fossil records that extend back to the early Cambrian ( 537 and $\sim 521$ million years ago respectively) (Daley et al., 2018). As the majority of these earliest euarthropods did not contain mineralised hard parts, we rely on remarkable fossil deposits such as the Burgess Shale, which preserve soft-bodied components of ancient biotas, to reveal critical data on the extraordinary diversity, disparity, and early evolution of Cambrian euarthropods (Gould, 1989).

Two of the most peculiar Burgess Shale animals, Anomalocaris and Opabinia, illustrate the complicated history of research of many Cambrian soft-bodied taxa - a result of their unfamiliar morphologies compared to the occupants of modern oceans (Collins, 1996; Briggs, 2015b). Both Anomalocaris and Opabinia possess compound eyes, lateral swimming flaps, filamentous setal structures, and a tail fan (Whittington, 1975; Whittington and Briggs, 1985; Budd and Daley, 2012; Daley and Edgecombe, 2014). Recent work has revealed that Anomalocaris and its relatives, the radiodonts, are united by the presence of paired sclerotized protocerebral frontal appendages and mouthparts composed of plates of multiple sizes, forming a diverse group containing over 20 taxa (Daley et al., 2009; Cong et al., 2014; Vinther et al., 2014; Van Roy, Daley and Briggs, 2015; Ortega-Hernández, Janssen and Budd, 2017; Lerosey-Aubril and Pates, 2018; Liu et al., 2018; Moysiuk and Caron, 2019). Radiodonts range in age from the early Cambrian to at least the Devonian, and have been recovered from numerous palaeocontinents (Kühl, Briggs and Rust, 2009; Daley and Budd, 2010; Cong et al., 2014; Daley and Legg, 2015; Van Roy, Daley and Briggs, 2015; Fu et al., 2019). Meanwhile, the most celebrated animal from the Burgess Shale (Budd, 1996; Briggs, 2015a), Opabinia regalis, with its head bearing five stalked eyes and a proboscis, remains the only opabiniid species confidently identified and is only known from a single quarry in the Burgess Shale. Myoscolex ateles from the Emu Bay Shale was proposed as a possible close relative (Briggs and Nedin, 1997), though this interpretation was hotly contested, and other authors have proposed a polychaete affinity (Glaessner, 1979; Dzik, 2004).

Radiodonts and Opabinia are now confidently placed within the lower stem of Euarthropoda (Budd, 1996; Daley et al., 2009; Ortega-Hernández, 2016), following the assignment of nearly all Cambrian soft-bodied animals to stem and crown groups of modern phyla (e.g. Budd and Jensen, 2000). Fossils illustrating the sequence of character evolution along the euarthropod stem lineage provide the framework for understanding the evolutionary origins of the segmented, modular exoskeleton and the specialized appendages that underpin the ecological success of this phylum (Ortega-Hernández, 2016). Difficulties remain in interpreting the anatomical details, morphology, and phylogenetic placement of exceptional Cambrian fossils. In Opabinia, the presence of lobopodous limbs in addition to the swimming flaps cannot be confirmed, and the architecture of the flaps and associated setal blades remains elusive (Budd, 1996; Zhang and Briggs, 2007; Budd and Daley, 2012). Consequently, the phylogenetic position of Opabinia relative to radiodonts and deuteropods remains hotly debated. The identification of 
plesiomorphic and apomorphic characters has required new imaging and reinterpretations of existing specimens, the discovery of new fossil material and localities, and, crucially, the improvement of phylogenetic analysis methods to evaluate alternative relationships of enigmatic taxa.

Here we redescribe a fossil specimen from the Drumian Wheeler Formation of Utah, previously described as an anomalocaridid radiodont (Briggs et al., 2008). KUMIP 314087 is a new genus and species that shares characters with both radiodonts and Opabinia regalis. We evaluate its phylogenetic position using both maximum parsimony (MP) and Bayesian inference (BI) and further interrogate the support for alternative relationships for KUMIP 314087 by visualizing the frequency and variation of these alternatives in treespace (Hillis, Heath and St. John, 2005; Wright and Lloyd, 2020). All analyses support an opabiniid affinity for KUMIP 314087. Our results evaluate the relative support for different hypotheses relating to the evolutionary acquisition of characters that define crown group euarthropods.

\section{Results}

Systematic Palaeontology.

Superphylum PANARTHROPODA Nielsen, 1995

Family OPABINIIDAE Walcott, 1912

Diagnosis. Panarthropod with a short head region bearing a single unjointed appendage ('proboscis'); slender trunk with dorsally transverse furrows delimiting segments; one pair of lateral flaps per body segment; setal blades cover at least part of anterior margin of lateral flaps; caudal fan composed of paired caudal blades; pair of short caudal rami with serrated adaxial margins.

Type genus. Opabinia Walcott, 1912.

Constituent taxa. KUMIP 314087 nov., Opabinia regalis Walcott, 1912.

Remarks. See supplementary materials.

Genus nov.

\section{Etymology. XXX}

Type material, locality, and horizon. KUMIP 314087, part only, a complete specimen preserved compressed dorso-laterally. Collected from strata of the upper Wheeler Formation (Miaolingian: Drumian), at the Carpoid Quarry (GPS: 39.290417, -113.278519), southwest Antelope Mountain, House Range, Utah, USA (Briggs et al., 2008).

Diagnosis. Opabiniid with slender trunk composed of at least 13, likely 15, segments; setal structures form blocks that cover the entire dorsal surface of the body and part of the anterior basal margin of the lateral flaps (setal blades only on flaps in Opabinia); tail fan composed of at least seven pairs of elongate caudal blades (three pairs in Opabinia).

Genus and species nov. gen. et sp.

Figs. 1b, c; 2b, d; 3 
Anomalocaris sp.: Briggs et al., p. 241, fig. 3

2015

Anomalocaris sp.: Robison, Babcock and Gunther, p. 54-55, fig. 153 (top left)

2021

Incertae sedis: Pates et al., p. 29, table 1.

Etymology. XXX

Diagnosis. As for genus, by monotypy.

Description. KUMIP 314087 represents a complete specimen preserved as a compression in dorsolateral view, with a length (sagittal) of $29 \mathrm{~mm}$ (Fig. 1). The overall organization consists of a short head, an elongate trunk with lateral body flaps, and a posterior tail fan.

The head region measures $\sim 10 \%$ of the total body length, and preserves traces of eyes, the mouth and the proboscis. In the ventral posterior region of the head, two curved red structures surround a circular opening, interpreted as a mouth opening ("mo" in Fig. 2b). The mouth opening is immediately proximal to a dark red region of two overlapping oval shapes, tentatively interpreted as a pair of lateral eyes ("ey?" in Fig. 2b). Ventral to this, a creamcoloured elongated conical structure extends from the head ventrally ("pb" in Fig. 2b), with a sub-millimetric orange linear structure of variable width located along its midline ("ic" in Fig. $\mathbf{2 b}$ ). This is tentatively identified as a proboscis with an internal cavity (Fig. $2 \mathbf{b}$ ).

The slender trunk ( $\sim 72 \%$ total body length) is widest towards the anterior and tapers towards the posterior. The dorsal margin bears a 'corrugated' appearance, with indents marking the point where dorsal intersegmental furrows intersect with the margin of the body ("df" in Figs. 1, 3). Blocks consisting of dozens of parallel darkly pigmented fine linear structures are arranged along the dorsal furrows and are interpreted as setal blades ("sb" in Figs. 1, 3). These blocks extend across the entire dorsal surface of the animal and continue laterally over the change in slope on the right side of the body. These setal structures display a triangular termination, which overlaps the anterior part of the base of the flaps (Figs. 1, 3).

At least 14, likely 15, of these lateral flaps are present on the right side of the body ("fl1?-15" in Fig. 1). Boundaries are not clear between what are interpreted as the two anteriormost flaps, and these may represent a single flap ("fl1?" in Fig. 1). Lateral flaps have a subtriangular outline and display a slight taper in size as the body thins posteriorly. The lateral flaps show reverse imbrication with the anterior margin of individual flaps overlapping the posterior margin of the flap immediately anterior to it. The surfaces of the flaps appear smooth and unornamented, with no evidence of strengthening rays or other internal features preserved, but the anterior margins of flaps 2-8 are preserved with a darker coloration compared to the inner region (Figs. 1, 3). Towards the posterior of the animal, a thin structure protruding from underneath a lateral flap could represent part of a ventral lobopodous limb, though the presence of additional material in the matrix of a similar width and orientation makes such an identification only very tentative ("Ill?" in Fig. 3). Structures of a similar width can be seen related to flaps seven and eight ("Ill?" in Fig. 1), though these may represent a poorly preserved anterior margin of these flaps. 
bioRxiv preprint doi: https://doi.org/10.1101/2021.03.10.434726; this version posted March 11, 2021. The copyright holder for this preprint (which was not certified by peer review) is the author/funder, who has granted bioRxiv a license to display the preprint in perpetuity. It is made available under aCC-BY 4.0 International license.
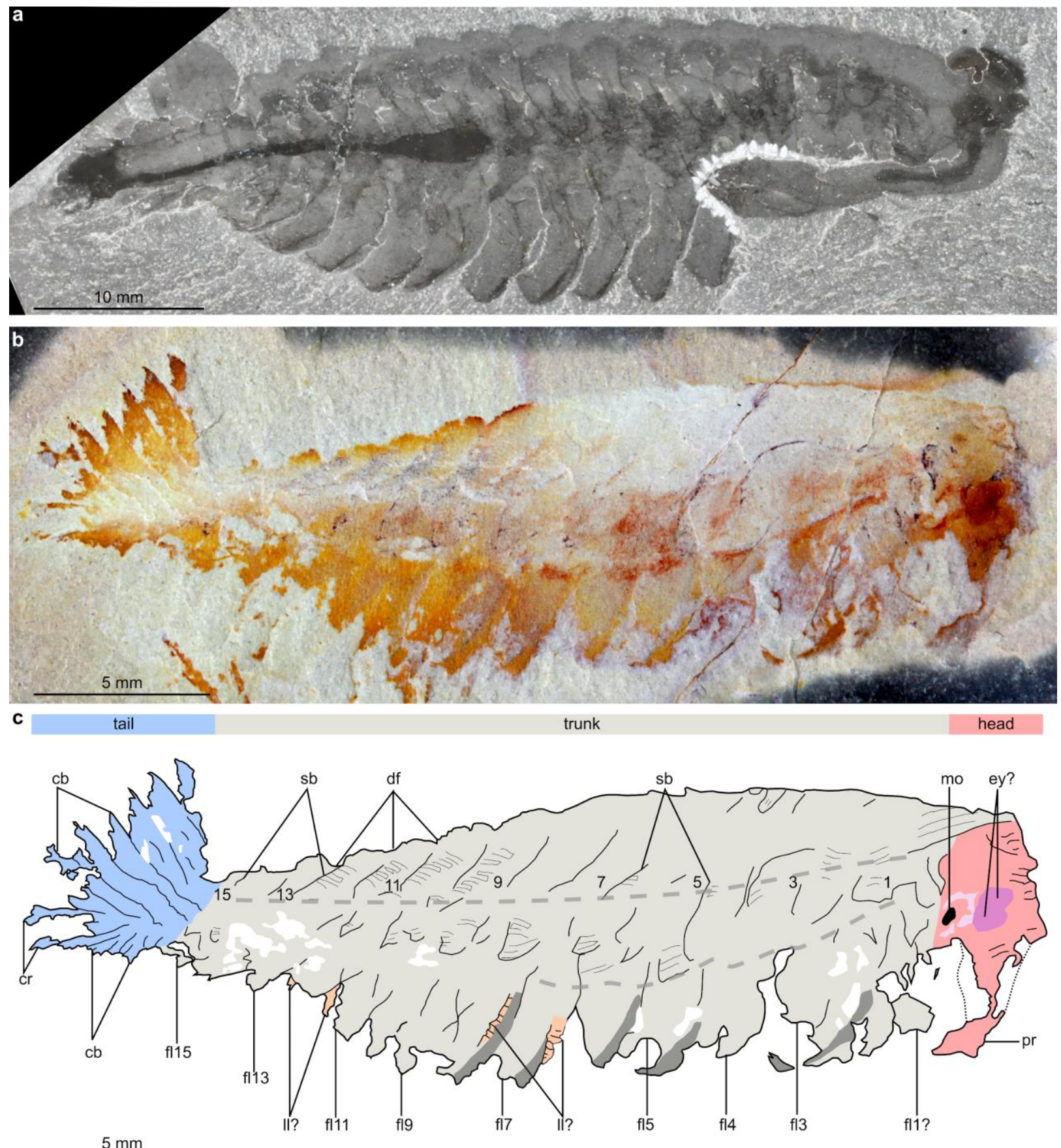

Figure 1. Comparison of Opabinia regalis Walcott, 1912 from the Burgess Shale (Cambrian: Wuliuan), British Columbia, Canada, and KUMIP 314087, gen. et sp. nov., from the Wheeler Formation (Cambrian: Drumian), House Range, Utah, USA. (a) USNM 155600, Opabinia regalis preserved in lateral view. (b) KUMIP 314087, preserved in dorsolateral view. (c) Interpretative drawing of panel B, dotted lines indicate inferred changes in slope on the body, numbers indicate body segments. Abbreviations: $c b$, caudal blade; $c r$, caudal ramus; $d f$, dorsally transverse furrow delineating trunk segments; ey?, dark oval structure in head region, potential eye; $f l$, lateral flap; $l l$ ? potential lobopodous limb; mo, mouth; $p r$, proboscis; $s b$, setal blade block. 
The posterior of the body ( $\sim 18 \%$ total body length) consists of a tail fan composed of paired elongate blades, and a pair of caudal rami. The tail has been twisted slightly and the right set of tail blades has been preserved flattened ventrally due to the dorsolateral aspect of preservation. The tail fan has seven, likely eight blades on the left side ("cb" in Fig. 2), while those on the right cannot be counted with certainty. Unlike the body flaps, these caudal blades are not associated with setal structures. They overlap one another proximally, a given blade largely concealing the blade immediately anterior to it. Each blade has the outline of an elongate parallelogram, longer on the anterior than posterior margin, and their acuminate distal regions splay out. The caudal rami are short ( $\sim 3 \mathrm{~mm}$ length), converge towards a common point at the posterior of the animal, extend from the body at a different angle to the caudal blades, and exhibit serrated axial margins ("cr" in Figs. 1, 2).
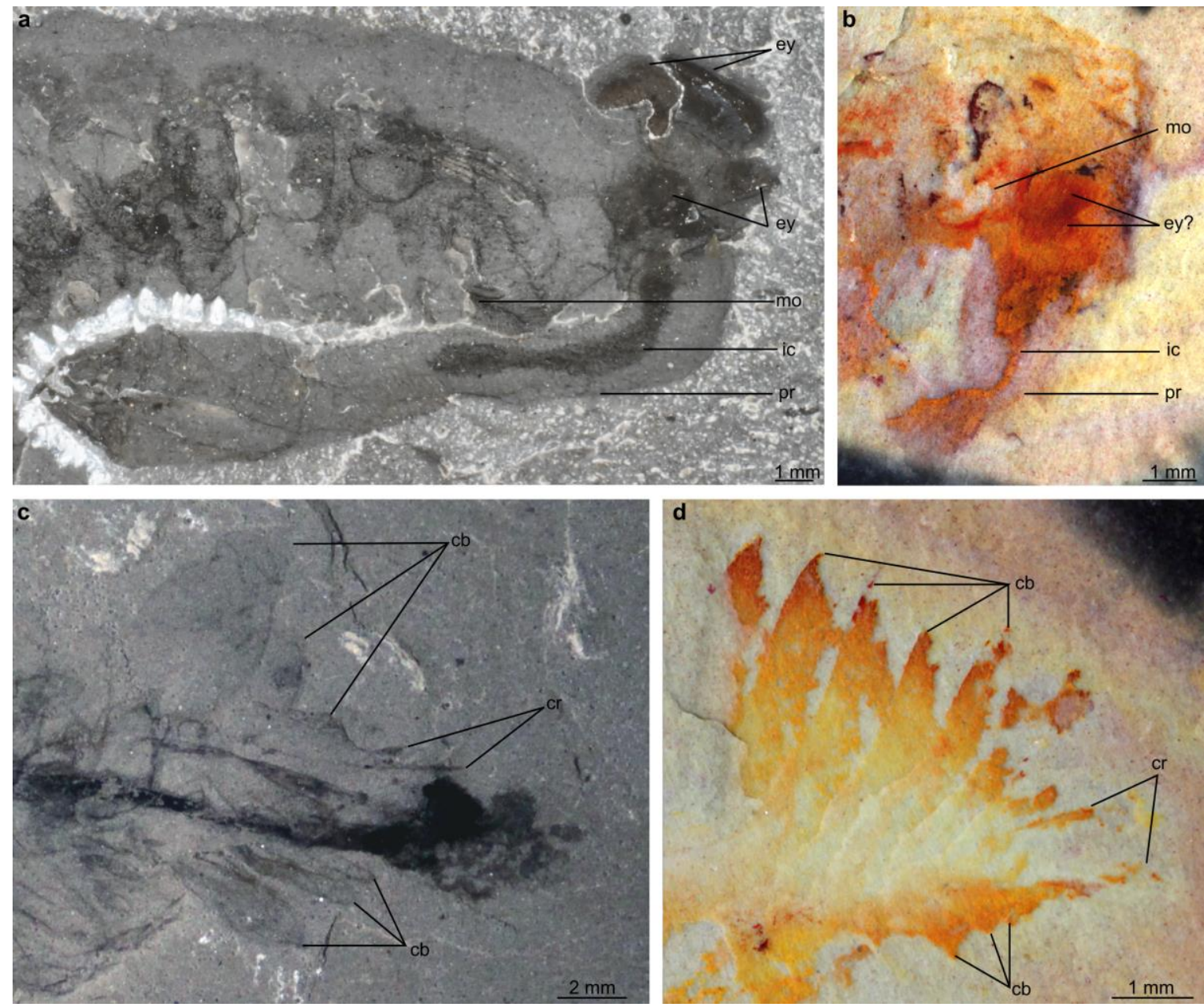

Figure 2. Details of the head and tail regions of Opabinia regalis Walcott, 1912 (a, c) and KUMIP 314087 gen. et sp. nov. (b, d). (a) Head region of USNM 155600, Opabinia regalis, showing eyes, posterior facing mouth, and proboscis with internal cavity. (b) Head region of KUMIP 314087, showing possible eyes, mouth, and putative proboscis with internal cavity. (c) Tail region of USNM 155600, Opabinia regalis, showing lobate tail blades, paired caudal rami with serrated adaxial margin, and posterior body termination extending beyond posteriormost caudal blades and caudal rami. (d) Tail region of KUMIP 314087 (photo mirrored), showing caudal blades and caudal rami with serrated adaxial margin. Abbreviations: $c b$, caudal blade; $c r$, caudal ramus; $e y$, eye; $i c$, internal cavity of proboscis; $m o$, mouth; $p r$, proboscis. 


\section{Remarks.}

KUMIP 314087 was originally described as an anomalocaridid radiodont based on the similarity in the shape of caudal blades to Anomalocaris taxa and the reverse imbrication of the flaps (Briggs et al., 2008). KUMIP 314087 also shares with radiodonts the presence of setal blades that extend over the dorsal midline of the body. The recognition herein of a putative proboscis with internal cavity, dorsally transverse furrows that delimit segments in the trunk, and a short pair of caudal rami with serrated axial margins, support closer affinities of this animal with Opabinia regalis, rather than with Anomalocaris. The unique combination of characters, and novel features such as the elaborate tail fan, warrant the erection of a new genus and species.

Among members of the euarthropod lower stem-group, a proboscis has only been reported previously in Opabinia (Whittington, 1975). The proboscis of KUMIP 314087 protrudes from the head in a similar position relative to the tentatively interpreted eyes as in Opabinia. In addition, a feature comparable to the internal cavity within the proboscis of Opabinia can be observed in KUMIP 314087 (Fig. 2). However, unlike Opabinia, no annulations can be seen in this structure, as it is too poorly preserved. KUMIP 314087 also has dorsal furrows delineating the body segments. Such dorsal epidermal segmentation is seen in Opabinia but is unknown in all other lower stem group euarthropods (including Kerygmachela, Pambdelurion and all radiodonts) (Ortega-Hernández, 2016).

KUMIP 314087 also displays characters known in both radiodonts and Opabinia. The slender, broadly rectangular dorsal outline of the body in KUMIP 314087 is comparable to what is observed in both Opabinia and the radiodonts Aegirocassis and Hurdia. This outline contrasts with the diamond-like outline of many radiodonts, including Amplectobelua symbrachiata, Anomalocaris canadensis, and Peytoia nathorsti (Whittington and Briggs, 1985; Chen, Ramsköld and Zhou, 1994; Daley and Edgecombe, 2014). In addition, both Opabinia and radiodonts possess setal blades, in varying arrangements (Supplementary Fig. 1). In Aegirocassis and Peytoia nathorsti, these structures form a single block per body segment, which covers the entire dorsal surface (Van Roy, Daley and Briggs, 2015), while in Opabinia the setal structures cover the anterior margin of the flaps (Budd and Daley, 2012). KUMIP 314087 appears to display a combination of these two states, with setal blades covering the dorsal surface in a single block, which extends laterally to the basal region of the anterior margins of corresponding flaps (Fig. 3). Strengthened anterior margins of lateral flaps have also been reported in a juvenile specimen of the amplectobeluid radiodont Lyrarapax (Liu et al., 2018). A tail fan associated with caudal rami is also known in both Opabinia and some radiodonts, though the number of blades known in KUMIP 314087 (at least seven, likely eight, on each side) by far exceeds what is known in either Opabinia (three) or any radiodont (ranging from zero to three). The acuminate tips of elongate caudal blades of KUMIP 314087 are most similar in morphology to those of Anomalocaris, and contrast to the more lobate caudal structures known in Opabinia and other radiodonts such as Hurdia (Fig. 2) (Whittington, 1975; Chen, Ramsköld and Zhou, 1994; Daley, Budd and Caron, 2013; Daley and Edgecombe, 2014). Paired caudal rami are also known in Anomalocaris saron, though these are much more elongate than in both KUMIP 314087 and Opabinia and lack the serrated adaxial margin common to the opabiniid taxa (Fig. 2) (Whittington, 1975; Chen, Ramsköld and Zhou, 1994). 


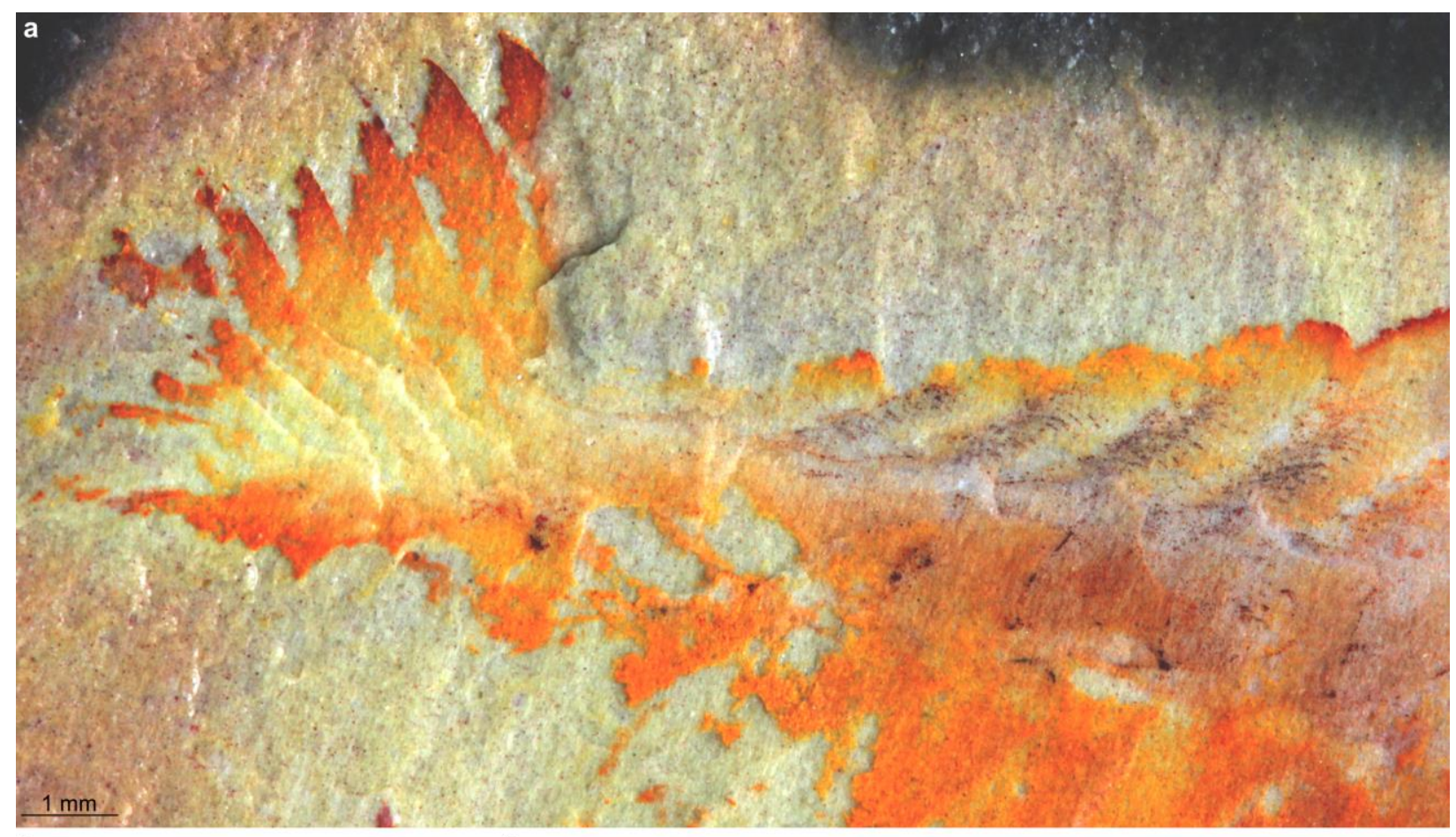

b

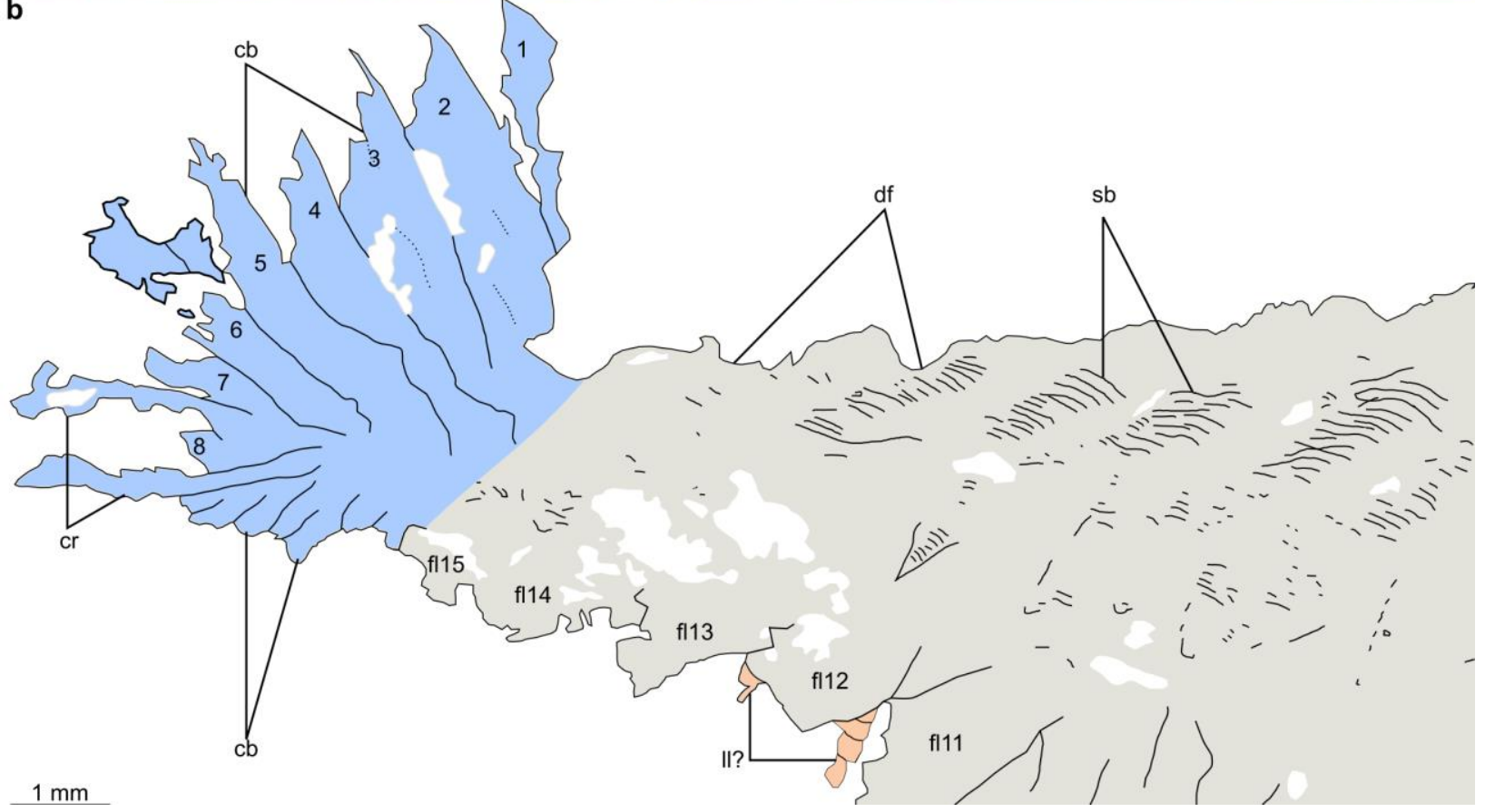

Figure 3. Posterior of KUMIP 314087 gen. et sp. nov. including details of setal blade blocks, elaborate tail fan, and paired caudal rami. (a) Photograph of specimen KUMIP 314097. (b) Interpretative drawing. Abbreviations: $c b$, caudal blade; $c r$, caudal ramus; $d f$, dorsally transverse furrow delineating trunk segments; $f l$, lateral flap; $s b$, setal blade block. 
Phylogenetic results. To test the affinities of KUMIP 314087 relative to Opabinia and radiodonts, we scored this specimen into a morphological matrix. Regardless of whether the matrix was analyzed with Bayesian inference (BI; Fig. 4a, Supplementary Fig. 2a, 2b) or maximum parsimony (MP; Supplementary Fig. 2c), a clade comprising KUMIP 314087 and Opabinia was resolved, warranting the assignment of the new taxon to family Opabiniidae. As the evidence for a proboscis in KUMIP 314087 is tentative (Fig. 2b), we conducted sensitivity analyses by building phylogenies where the proboscis (character 14) was coded as uncertain. With BI, opabiniids remained monophyletic (with lower nodal support; Supplementary Figs. 3a, 3b). With MP and an uncertain proboscis, the monophyly of opabiniids collapsed to a polytomy with deuteropods (Supplementary Fig. 3c).
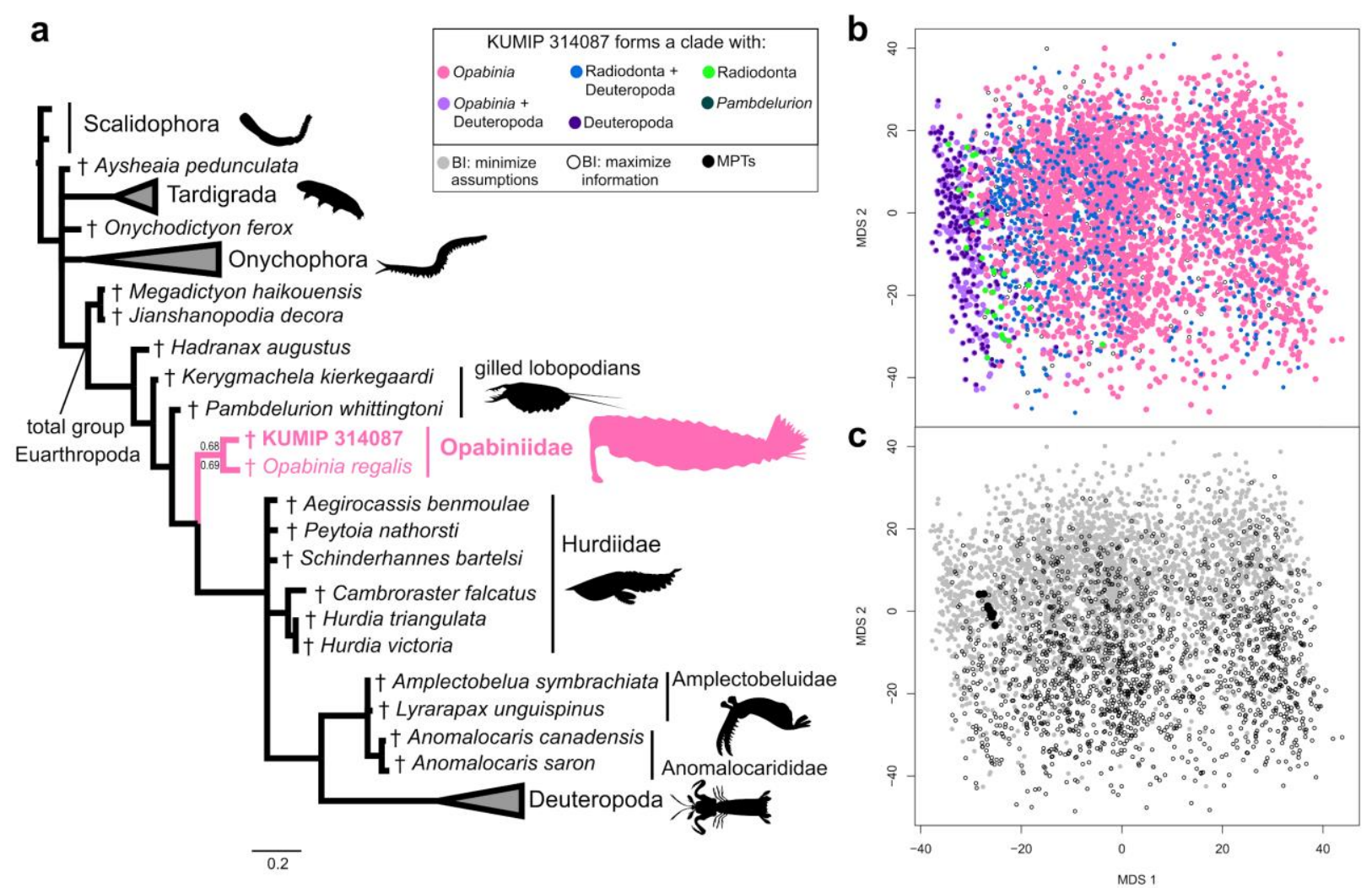

Figure 4. Phylogenetic relationships of opabiniids and lower stem group euarthropods. (a) Summarized topology based on the consensus tree retrieved with BI under minimize assumptions parameters. Numbers at the key node indicate posterior probabilities from this analysis, and from BI under maximize information parameters. Credits for silhouettes: Priapulus caudatus: Bruno C. Vellutini (CC BY 3.0); Hurdia victoria and Anomalocaris canadensis: Caleb M Brown (CC BY-SA 3.0) (b) Treespace plotted by bipartition resolving KUMIP 314087. Points are colored by relationships for this taxon. (c) Treespace plotted by analysis.

As the support values were poor for a morphological analysis (Fig. 4a, Supplementary Fig. 2: posterior probabilities of 0.68 and 0.69 with BI; jackknife value of 57 and GC value of 65 with MP), we visualized treespace (Hillis, Heath and St. John, 2005). Such plots identify whether uncertainty in support for opabiniid relationships in the posterior sample $(n=4512$ trees for analyses where proboscis is coded as present; Table 1) and MPTs ( $n=12$ trees) is restricted to tree islands with otherwise similar topologies, or spread throughout a large region of occupied 
Table 1. Number of trees bearing each bipartition of interest under different analytical regimes, with the total number of trees retrieved by each analysis in the last row. Categories are not mutually exclusive (e.g. Opabinia + Deuteropoda contains Opabinia only and Deuteropoda only trees), therefore the total of all rows exceeds the total number of trees in the analysis.

\begin{tabular}{|c|c|c|c|c|c|c|}
\hline \multirow{2}{*}{$\begin{array}{l}\text { KUMIP } 314087 \\
\text { forms a clade } \\
\text { with }\end{array}$} & \multicolumn{3}{|c|}{ Proboscis present } & \multicolumn{3}{|c|}{ Proboscis uncertain } \\
\hline & $\begin{array}{l}\text { Minimize } \\
\text { assumptions }\end{array}$ & $\begin{array}{l}\text { Maximize } \\
\text { information }\end{array}$ & MP & $\begin{array}{l}\text { Minimize } \\
\text { assumptions }\end{array}$ & $\begin{array}{l}\text { Maximize } \\
\text { information }\end{array}$ & MP \\
\hline Opabinia & 1941 & 1149 & 12 & 1573 & 884 & 10 \\
\hline $\begin{array}{l}\text { Deuteropoda }+ \\
\text { Radiodonta } \\
\text { (excludes } \\
\text { Opabinia) }\end{array}$ & 460 & 307 & 0 & 552 & 394 & 0 \\
\hline $\begin{array}{l}\text { Opabinia }+ \\
\text { Deuteropoda }\end{array}$ & 359 & 105 & 12 & 401 & 104 & 12 \\
\hline Deuteropoda & 186 & 65 & 0 & 225 & 73 & 2 \\
\hline Radiodonta & 14 & 14 & 0 & 24 & 27 & 0 \\
\hline Pambdelurion & 1 & 0 & 0 & 3 & 5 & 0 \\
\hline Kerygmachela & 0 & 0 & 0 & 1 & 0 & 0 \\
\hline Hurdiidae & 0 & 0 & 0 & 0 & 1 & 0 \\
\hline $\begin{array}{l}\text { None of the } \\
\text { above }\end{array}$ & 132 & 87 & 0 & 173 & 99 & 0 \\
\hline Total trees & 2856 & 1656 & 12 & 2704 & 1512 & 12 \\
\hline
\end{tabular}

treespace. While treespace has been previously explored in meta-analyses of fossil datasets (Brazeau, Guillerme and Smith, 2019; Koch and Parry, 2020; Wright and Lloyd, 2020), this is, to our knowledge, the first attempt to use such a visualization to interrogate the distribution of bipartitions for the position of a focal fossil taxon. Several possible hypotheses are subsets: KUMIP 314087 could be part of a clade with either Opabinia or Deuteropoda (pink and dark purple colors, respectively, in Fig. 4b), and could be part of both those clades (light purple in Fig. 4b). Our overall treespace for KUMIP 314087 can nevertheless be grouped by islands of trees where the supermajority of trees are related to opabiniids ( $n=3102$ trees total for analyses where proboscis is coded as present) or a minority to deuteropods ( $n=251$ trees total). A sparse, slender zone ( $n=28$ trees total) of the alternative exclusive hypothesis that KUMIP 314087 is a radiodont (Briggs et al., 2008) transitions between the opabiniid and deuteropod islands. Interspersed sparsely within the opabiniid island are topologies supporting KUMIP 314087 with both radiodonts and deuteropods, but excluding Opabinia (blue in Fig. 4b); most of these trees depict Opabinia as the direct outgroup rather than a wildcard taxon (occupying different 
positions that are topologically distant). Choice of BI model parameters did not substantially impact the treespace (Fig. 4c: grey and open circles overlap completely on axis 1 and much of axis 2), while the MPTs (Fig. 4c: black circles) formed a small but distinct cluster.

\section{Discussion}

The power of treespace for phylogenetic uncertainty of fossils. At first glance, our phylogenetic analyses provide only weak nodal support for the placement of KUMIP 314087 within Opabiniidae. Although similar nodal support with a similar data matrix has been used to reclassify enigmatic fossils (Howard et al., 2020), we further interrogated our results - especially important as our terminal of interest is represented by a single specimen. Therefore, we investigated the degree of uncertainty in bipartitions, finding an increased number of topologies (Table 1) that support KUMIP 314087 related to at least one opabiniid, and not to an alternative taxon. Such calculations have been effective in summarizing the taxonomic uncertainty in fossil placement (Klopfstein and Spasojevic, 2019). Furthermore, our visualization of the sample of optimal trees (Hillis, Heath and St. John, 2005; St. John, 2017; Wright and Lloyd, 2020) illustrates the distribution of topological distances between conflicting and overlapping hypotheses. This technique allows the strength of support for competing hypotheses of relationships to be more comprehensively evaluated beyond an arbitrary cutoff value.

Phylogenetic analyses aiming to resolve the relationships of fossil taxa present challenges such as researcher-specific morphological interpretation and coding decisions, preponderance of missing data (common for exceptionally preserved Cambrian taxa, due to preservation of few specimens or taphonomic loss of labile morphology), and relatively simple models of character change that may not reflect true evolutionary history (Sansom, Gabbott and Purnell, 2010; Watanabe, 2016; Tarasov, 2019; Wright, 2019). Visualization of treespace investigates how these scenarios may affect a consensus topology. In the case of KUMIP 314087, the morphological description is based on a single specimen where we could only tentatively identify the proboscis. Therefore, we compared alternative codings to represent our uncertainty in interpretation, and the potential influence on the definition of opabiniids (Supplementary Figs. 3, 4). The sister group relationship of KUMIP 314087 with Opabinia (rather than radiodonts or deuteropods) is not driven by the proboscis character, and is maintained due to the other shared morphological characters (e.g. dorsal furrows, caudal rami).

Implications for opabiniid evolution and ecology. Our phylogenetic results provide substantial support for an assignment of KUMIP 314087 to Opabiniidae, helping to clarify some debates about the morphology of Opabinia. Enigmatic triangular structures found along the body in Opabinia, have been variously interpreted as extensions of the gut (Whittington, 1975; Zhang and Briggs, 2007), or as lobopodous walking limbs (Budd, 1996; Budd and Daley, 2012). The potential lobopods extending from the ventral surface in KUMIP 314087 suggest that these walking limbs may be present in opabiniids generally. Additionally, two contrasting interpretations have been presented for the relationship between the lateral flaps and the blocks of setal blades in Opabinia: one where the setal blades are attached to the dorsal surface of the lateral flaps (Budd, 1996; Budd and Daley, 2012), and the other view suggesting the setal blades were attached as a fringe along the posterior margin of the lateral flap (Zhang and Briggs, 2007). The setal blades in KUMIP 314087 support the former interpretation, with the setal blades 
extending mainly along the dorsal surface of the body but also along the basal anterior margin of the flaps. Evidently the addition of even a single new specimen to the opabiniids provides crucial data informing on the group's morphological aspects.

The family Opabiniidae is now considered to comprise two taxa, expanding its range geographically from two quarries separated by only a few meters to two deposits $\sim 1000 \mathrm{~km}$ apart during two Cambrian Stages (Nanglu, Caron and Gaines, 2020). Although both Opabinia and Anomalocaris underwent major redescriptions around the same time (Whittington, 1975; Briggs, 1979; Whittington and Briggs, 1985), our revised opabiniids have not nearly caught up to the known diversity or distribution of radiodonts (or even the monophyletic groupings recovered in this study, Hurdiidae and Amplectobeluidae + Anomalocarididae). Radiodont frontal appendages, mouthparts, and carapaces are sclerotized and are often among the first fossils recovered from Cambrian deposits preserving non-biomineralizing organisms, and indeed many radiodont taxa are only known from their frontal appendages (e.g. Daley and Budd, 2010; Pates and Daley, 2019). However, preservation potential alone is insufficient to account for the greater diversity and distribution of radiodonts relative to opabiniids, as even radiodonts known only from complete specimens greatly outnumber opabiniids, both globally and within the Burgess Shale. Thus, the absence of opabiniids in other deposits from which complete radiodonts are known likely reflects a true absence or much lower diversity, which could have an ecological explanation.

Following a renaissance in radiodont research, it has been recognised that radiodonts display impressive variation in body size (milimetre to metre scale), body shape (rectangular to diamond shape in outline), inferred feeding ecology (raptorial predators, sediment sifters, filter feeders), and niche differentiation where species co-occur (e.g. Daley and Budd, 2010; Daley, Budd and Caron, 2013; Daley and Edgecombe, 2014; Vinther et al., 2014; Van Roy, Daley and Briggs, 2015; Lerosey-Aubril and Pates, 2018; Liu et al., 2018; Moysiuk and Caron, 2019; Lerosey-Aubril et al., 2020; Pates et al., 2021). In contrast, opabiniids show limited evidence for adaptations to different niches. Both taxa have rectangular body shapes and are centimetre scale (the single specimen KUMIP 314087 is $~ 50 \%$ the length of the largest Opabinia). The more elaborate tailfan of KUMIP 314087 may indicate a greater maneuverability of this taxon compared to Opabinia regalis, as the tailfan of Anomalocaris canadensis aided swift changes in direction (Sheppard, Rival and Caron, 2018).

Implications for the euarthropod stem group. Our results have implications for larger scale questions, such as the relative phylogenetic positions of opabiniids and radiodonts along the euarthropod stem group, and detailed consideration of conflicting topologies. We replicate the dichotomy of recent publications, where matrices analyzed using MP find opabiniids as the sister group to deuteropods (Yang et al., 2016, 2018; Howard et al., 2020) and those analyzed using BI or maximum likelihood instead resolve radiodonts in that position (Fleming et al., 2018; Moysiuk and Caron, 2019; Howard et al., 2020; Zeng et al., 2020). The branching order of these three clades has ramifications for the sequence of acquisition, and evolutionary reversals or convergences, of key crown group euarthropod characters (Ortega-Hernández, 2016), such as the posterior mouth and arthropodized appendages, as well as the dorsal expression of trunk segmentation (Supplementary Fig. 5). The scenario (favored by MP and an island of BI topologies) where opabiniids are sister group to deuteropods requires either the secondary loss of 
arthropodized appendages in opabiniids, or the convergent evolution of arthropodized appendages in radiodonts and deuteropods.

The consensus topology (Fig. 4a, Supplementary Fig. 5a), and the majority of topologies (yellow, pink, and maroon points in Supplementary Fig. 5c), support a single origin of arthropodization in euarthropods. A possible developmental framework would entail the single anterior protocerebral pair of arthropodized limbs in radiodonts becoming co-opted posteriorly to enable the arthropodization of all limbs (Jockusch, 2017; Chipman and Edgecombe, 2019). This scenario would require the convergent fusion of presumed protocerebral appendages in opabiniids to form a single proboscis, and of protocerebral limb buds in deuteropods to form the labrum (Chipman, 2015; Jockusch, 2017; Ortega-Hernández, Janssen and Budd, 2017; Park et al., 2018). Evolutionary reversals or convergences are also required by these topologies (Supplementary Figs. 5, 6). The posterior-facing mouth shared by Opabinia and deuteropods is either convergent or lost in radiodonts (Ortega-Hernández, Janssen and Budd, 2017). Additionally, the distinct dorsally transverse furrows delineating segment boundaries (reported in both opabiniids), which may represent a precursor to arthrodized tergites in deuteropods (Yang et al., 2015), could either be lost in radiodonts and regained in deuteropods, or represent a convergent expression of dorsal trunk segmentation.

The consensus topology is further complicated by the apparent paraphyly of radiodonts (Fig. 4A, Supplementary Figs. 2a, 2b, 3b). Traditional nodal support resolves a clade of amplectobeluids, anomalocaridids, and deuteropods with posterior probabilities of 0.52-0.61 (Supplementary Figs. 2a, 2b, 3a, 3b). The specific relationship of amplectobeluids and anomalocaridids with deuteropods might improve some aspects of limb evolution, as the loss of dorsal flaps (shared by opabiniids and hurdiids; Supplementary Fig. 1) prior to the proposed fusion of setal blades and ventral flaps into the deuteropod biramous limb removes the requirement to identify a dorsal flap homolog in deuteropods (Van Roy, Daley and Briggs, 2015). However, treespace visualization does not provide strong support for radiodont paraphyly, as overlapping islands resolve conflicting relationships among radiodonts and deuteropods (Supplementary Figs. 5c, 7, supplementary discussion). As many of the characters distinguishing internal relationships among radiodont families describe the protocerebral frontal appendages, and are coded as inapplicable to all other taxa, we propose revised models of character evolution (Tarasov, 2019; Wright, 2019) may be necessary to resolve these relationships; accordingly we place little weight on this particular result. It should be emphasized, however, that the position of KUMIP 314087 is not affected by this uncertainty, as its position as sister taxon to each radiodont clade was tested (with only non-zero results reported in Table 1).

Conclusions. The "weird wonders", as popularized by (Gould, 1989), inspired a generation of Cambrian paleontologists, with Opabinia at the heart of his narrative. The reorganization of previously enigmatic Cambrian taxa into stem groups instead revealed their importance for reconstructing the origins of modern phyla. Resolving the phylogenetic placement of these species is crucial for understanding the sequence of evolution of diagnostic crown group characters, as well as reconstructing the diversity and paleogeography of early ecosystems and groups. Here we apply treespace visualization to the reinterpretation of the relatively poorly preserved fossil KUMIP 314087. Dissection of the phylogenetic support 
demonstrates that while evidence for radiodont paraphyly is weak, KUMIP 314087 can be confidently reassigned to Opabiniidae. The weirdest wonder of the Cambrian no longer stands alone.

\section{Methods}

Fossil imaging and measurements. KUMIP 314087, accessioned at the Biodiversity Institute, University of Kansas, Lawrence, Kansas, USA (KUMIP), was photographed using a Canon EOS 500D digital SLR camera and Canon EF-S $60 \mathrm{~mm}$ Macro Lens, controlled for remote shooting using EOS Utility 2. Comparative figured material of Opabinia regalis is accessioned at the Smithsonian Institution U. S. National Museum of Natural History (USNM). Both polarized and unpolarized lighting were employed, with the fossil surface both wet and dry. Measurements were taken digitally using ImageJ2 (Rueden et al., 2017).

Morphological matrix. We added five fossil taxa (KUMIP 314087, Amplectobelua symbrachiata Hou, Bergström and Ahlberg 1995, Anomalocaris saron Hou, Bergström and Ahlberg 1995, Cambroraster falcatus Moysiuk and Caron 2019, and Hurdia triangulata Walcott 1912) and removed one fossil ('Siberian Orsten tardigrade') from a previously published morphological data matrix of panarthropods (Yang et al., 2016), for a total of 43 fossil and 11 extant taxa. 86 characters were retained from the original matrix, 14 characters were added from two radiodont-focused datasets (Lerosey-Aubril and Pates, 2018; Moysiuk and Caron, 2019), and 25 characters were newly developed or substantially modified herein, for a total of 125 discrete morphological characters. Details of all characters including original and new character descriptions and scorings may be downloaded from MorphoBank (O'Leary and Kaufman, 2012) (www.morphobank.org, reviewer login 'email address': 3874, reviewer password: opabiniids).

Phylogenetic analysis. The primary phylogenetic analyses were conducted using BI in MrBayes v.3.2.7 (Ronquist et al., 2012), implementing the Markov (Mk) model (Lewis, 2001) of character change under two different parameter regimes. We followed the 'maximize information' and 'minimize assumptions' strategies of Bapst, Schreiber and Carlson (2018). The 'maximize information' strategy assumes equal rate distribution across characters and that state frequencies are in equilibrium, as in most previously published BI morphological studies. The 'minimize assumptions' strategy (a) applies gamma distributed among-character rate variation, and $(b)$ varies the symmetric Dirichlet hyperprior with a uniform distribution of $(0,10)$ to relax assumptions about character state frequency transitions (Wright, Lloyd and Hillis, 2016). As with complex molecular substitution models, the 'minimize assumptions' strategy may allow a better fit of the model to the data. Each analysis implemented four runs of four chains each (for 5.5 million and 9.5 million generations, respectively), with $25 \%$ burnin. Convergence was assessed based on standard deviations of split frequencies $<0.01$, reaching effective sample size $>200$ for every parameter, and by comparing posterior distributions in Tracer v.1.7.1 (Rambaut et al., 2018).

As the original matrix (Yang et al., 2016) was devised for MP analysis, we explored MP topologies in TNT v.1.5 (Goloboff and Catalano, 2016) using implied weights $(k=3)$ and New Technology. We required the shortest tree to be retrieved 100 times, using tree bisectionreconnection to swap one branch at a time on the trees in memory (Wolfe and Hegna, 2014). 
Treespace analysis. Supplemental to traditional clade support metrics, we used classical multidimensional scaling (MDS) to plot treespace (Gower, 1966; Hillis, Heath and St. John, 2005; St. John, 2017; Wright and Lloyd, 2020), with the goal of identifying the distribution of trees resolving key clades formed with KUMIP 314087 (Table 1). Our R script inputs the unrooted post-burnin posterior samples (resultant from BI) and MPTs (resultant from MP) using ape v.5.3 (Paradis and Schliep, 2019), and employs phangorn v.2.5.5 (Schliep, 2011) to calculate pairwise unweighted Robinson-Foulds distances (RF, the proportion of bipartitions defined by a branch in one tree that is lacking in another tree) (Robinson and Foulds, 1981) for the total set of trees resulting from all analyses. The classical MDS function is performed on the RF distances, with a constant added to all elements in the distance matrix to correct for negative eigenvalues (Cailliez, 1983). The treespace therefore approximates the RF distances between trees (Hillis, Heath and St. John, 2005).

Data availability. Supplementary data files are available at MorphoBank (www.morphobank.org, reviewer login ('email address'): 3874, reviewer password: opabiniids) and at the Dryad Digital Repository, provisional link: https://datadryad.org/stash/share/VnOhPzM8ckUliq1W9roY9dnMFi6qLOacYKiG1cs2GA8. Nomenclatural acts relating to the new taxon will be registered on ZooBank, LSIDXXX (publication), LSIDXXY (genus), LSIDXXZ (species).

\section{Acknowledgements}

We are particularly grateful to P. Reese, who collected KUMIP 314087 and generously donated it to the Biodiversity Institute, University of Kansas (KUMIP). Access to and loan of this specimen was facilitated by B.S. Lieberman and J. Kimmig (KUMIP). J.O.H. thanks S. Whittaker (Smithsonian Institution) for facilitating access and training to imaging facilities. We thank M.J. Hopkins (American Museum of Natural History) and L.T. Rangel (Massachusetts Institute of Technology) for discussions about treespace, and F. Anthony for collaboration on the fossil reconstruction. S.P. acknowledges funding from an Alexander Agassiz Postdoctoral Fellowship (Museum of Comparative Zoology, Harvard University) and a Herchel Smith Postdoctoral Fellowship (University of Cambridge). This work was also supported by the National Science Foundation DEB \#1856679 to J.M.W. and J.O.H.

\section{Author contributions}

SP and JMW wrote the manuscript and created all the figures. All authors edited the text with critical insights. ACD, SP and JOH photographed fossil material. SP and JMW created the character matrix and coded taxa, with input from all other authors. SP led the fossil interpretation. JMW conceived and led the phylogenetic and treespace analyses.

\section{Competing interests}

The authors declare no competing interests. 


\section{References}

Bapst, D. W., Schreiber, H. A. and Carlson, S. J. (2018) 'Combined Analysis of Extant Rhynchonellida (Brachiopoda) using Morphological and Molecular Data', Systematic Biology, 67(1), pp. 32-48. doi: 10.1093/sysbio/syx049.

Brazeau, M. D., Guillerme, T. and Smith, M. R. (2019) 'An algorithm for Morphological Phylogenetic Analysis with Inapplicable Data', Systematic Biology, 68(4), pp. 619-631. doi: 10.1093/sysbio/syy083.

Briggs, D. E. G. (1979) 'Anomalocaris, the largest known Cambrian arthropod', Palaeontology, 22(3), pp. 631-664.

Briggs, D. E. G. et al. (2008) 'Middle Cambrian arthropods from Utah', Journal of Paleontology, 82(2), pp. 238-254. doi: 10.1666/06-086.1.

Briggs, D. E. G. (2015a) 'Extraordinary fossils reveal the nature of Cambrian life: a commentary on Whittington (1975) "The enigmatic animal Opabinia regalis, Middle Cambrian, Burgess Shale, British Columbia"', Philosophical Transactions of the Royal Society B: Biological Sciences, 370(20143013), pp. 1-10. doi: 10.1098/rstb.2014.0313.

Briggs, D. E. G. (2015b) 'The Cambrian explosion', Current Biology, 25(19), pp. R864-R868. doi: 10.1016/j.cub.2015.04.047.

Briggs, D. E. G. and Nedin, C. (1997) 'The Taphonomy and Affinities of the Problematic Fossil Myoscolex from the Lower Cambrian Emu Bay Shale of South Australia', Journal of Paleontology, 71(1), pp. 22-32.

Budd, G. E. (1996) 'The morphology of Opabinia regalis and the reconstruction of the arthropod stem-group', Lethaia, 29(1), pp. 1-14. doi: 10.1111/j.1502-3931.1996.tb01831.x.

Budd, G. E. and Daley, A. C. (2012) 'The lobes and lobopods of Opabinia regalis from the middle Cambrian Burgess Shale', Lethaia, 45(1), pp. 83-95. doi: 10.1111/j.15023931.2011.00264.x.

Budd, G. E. and Jensen, S. (2000) 'A critical reappraisal of the fossil record of the bilaterian phyla’, Biological Reviews, 75(2), pp. 253-295. doi: 10.1111/j.1469-185X.1999.tb00046.x.

Cailliez, F. (1983) 'The analytical solution of the additive constant problem', Psychometrika, 48(2), pp. 305-308. doi: 10.1007/BF02294026.

Chen, J. Y., Ramsköld, L. and Zhou, G. Q. (1994) 'Evidence for monophyly and arthropod affinity of Cambrian giant predators', Science, 264(5163), pp. 1304-1308. doi:

10.1126/science.264.5163.1304.

Chipman, A. D. (2015) 'An embryological perspective on the early arthropod fossil record Evolutionary developmental biology and morphology', BMC Evolutionary Biology, 15(1), pp. 118. doi: 10.1186/s12862-015-0566-Z. 
Chipman, A. D. and Edgecombe, G. D. (2019) 'Developing an integrated understanding of the evolution of arthropod segmentation using fossils and evo-devo', Proceedings of the Royal Society B: Biological Sciences, 286(20191881), pp. 1-11. doi: 10.1098/rspb.2019.1881.

Collins, D. (1996) 'The "Evolution" of Anomalocaris and Its Classification in the Arthropod Class Dinocarida (nov.) and Order Radiodonta (nov.)', Journal of Paleontology, 70(2), pp. 280293.

Cong, P. et al. (2014) 'Brain structure resolves the segmental affinity of anomalocaridid appendages', Nature, 513(7519), pp. 538-542. doi: 10.1038/nature13486.

Daley, A. C. et al. (2009) 'The Burgess Shale Anomalocaridid Hurdia and Its Significance for Early Euarthropod Evolution', Science, 323(20 March), pp. 1597-1600.

Daley, A. C. et al. (2018) 'Early fossil record of Euarthropoda and the Cambrian Explosion', Proceedings of the National Academy of Sciences of the United States of America, 115(21), pp. 5323-5331. doi: 10.1073/pnas.1719962115.

Daley, A. C. and Budd, G. E. (2010) 'New anomalocaridid appendages from the Burgess Shale, Canada', Palaeontology, 53(4), pp. 721-738. doi: 10.1111/j.1475-4983.2010.00955.

Daley, A. C., Budd, G. E. and Caron, J.-B. (2013) 'Morphology and systematics of the anomalocaridid arthropod Hurdia from the Middle Cambrian of British Columbia and Utah', Journal of Systematic Palaeontology, 11(7), pp. 743-787. doi: 10.1080/14772019.2012.732723.

Daley, A. C. and Edgecombe, G. D. (2014) 'Morphology of Anomalocaris canadensis from the Burgess Shale', Journal of Paleontology, 88(1), pp. 68-91. doi: 10.1666/13-067.

Daley, A. C. and Legg, D. A. (2015) 'A morphological and taxonomic appraisal of the oldest anomalocaridid from the Lower Cambrian of Poland', Geological Magazine, 152(5), pp. 949955. doi: 10.1017/S0016756815000412.

Dzik, J. (2004) 'Anatomy and relationships of the Early Cambrian worm Myoscolex', Zoologica Scripta, 33(1), pp. 57-69. doi: 10.1111/j.1463-6409.2004.00136.x.

Fleming, J. F. et al. (2018) 'Molecular palaeontology illuminates the evolution of ecdysozoan vision', Proceedings of the Royal Society B: Biological Sciences, 285(20182180), pp. 1-9. doi: 10.1098/rspb.2018.2180.

Fu, D. et al. (2019) 'The Qingjiang biota-A Burgess Shale-type fossil Lagerstätte from the early Cambrian of South China', Science, 363(6433), pp. 1338-1342. doi: 10.1126/science.aau8800.

Glaessner, M. F. (1979) 'Lower Cambrian Crustacea and annelid worms from Kangaroo Island, South Australia', Alcheringa, 3(1), pp. 21-31. doi: 10.1080/03115517908565437.

Goloboff, P. A. and Catalano, S. A. (2016) 'TNT version 1.5 including a full implementation of phylogenetic morphometrics', Cladistics, 32, pp. 221-238. 
Gould, S. J. (1989) Wonderful Life: The Burgess Shale and the Nature of History. W. W. Norton $\&$ Co.

Gower, J. C. (1966) 'Some distance properties of latent root and vector methods used in multivariate analysis', Biometrika, 53(3-4), pp. 325-338.

Hillis, D. M., Heath, T. A. and St. John, K. (2005) 'Analysis and visualization of tree space', Systematic Biology, 54(3), pp. 471-482. doi: 10.1080/10635150590946961.

Hou, X., Bergström, J. and Ahlberg, P. (1995) 'Anomalocaris and other large animals in the Lower Cambrian Chengjiang fauna of southwest China', GFF, 117(3), pp. 163-183. doi: 10.1080/11035899509546213.

Howard, R. J. et al. (2020) 'A Tube-Dwelling Early Cambrian Lobopodian', Current Biology, 30(8), pp. 1529-1536.e2. doi: 10.1016/j.cub.2020.01.075.

Jockusch, E. L. (2017) 'Developmental and evolutionary perspectives on the origin and diversification of arthropod appendages', Integrative and Comparative Biology, 57(3), pp. 533545. doi: 10.1093/icb/icx063.

Klopfstein, S. and Spasojevic, T. (2019) 'Illustrating phylogenetic placement of fossils using RoguePlots: An example from ichneumonid parasitoid wasps (Hymenoptera, Ichneumonidae) and an extensive morphological matrix', PLOS ONE, 14(e0212942), pp. 1-27. doi: https://doi.org/10.1371/journal. pone.0212942.

Koch, N. M. and Parry, L. A. (2020) 'Death is on our side: Paleontological data drastically modify phylogenetic hypotheses’, Systematic Biology, 69(6), pp. 1052-1067. doi: 10.1093/sysbio/syaa023.

Kühl, G., Briggs, D. E. G. and Rust, J. (2009) 'A great-appendage arthropod with a radial mouth from the Lower Devonian Hunsrück Slate, Germany', Science, 323(5915), pp. 771-773. doi: $10.1126 /$ science. 1166586 .

Lerosey-Aubril, R. et al. (2020) 'New exceptionally preserved panarthropods from the Drumian Wheeler Konservat-Lagerstätte of the House Range of Utah', Papers in Palaeontology, 6(4), pp. 501-531. doi: 10.1002/spp2.1307.

Lerosey-Aubril, R. and Pates, S. (2018) 'New suspension-feeding radiodont suggests evolution of microplanktivory in Cambrian macronekton', Nature Communications, 9(1), pp. 1-9. doi: 10.1038/s41467-018-06229-7.

Lewis, P. O. (2001) 'A likelihood approach to estimating phylogeny from discrete morphological character data', Systematic Biology, 50(6), pp. 913-925. doi: 10.1080/106351501753462876.

Liu, J. et al. (2018) 'Origin of raptorial feeding in juvenile euarthropods revealed by a Cambrian radiodontan', National Science Review, 5(6), pp. 863-869. doi: 10.1093/nsr/nwy057.

Moysiuk, J. and Caron, J.-B. (2019) 'A new hurdiid radiodont from the Burgess Shale evinces 
the exploitation of Cambrian infaunal food sources', Proceedings of the Royal Society B: Biological Sciences, 286(1908). doi: 10.1098/rspb.2019.1079.

Nanglu, K., Caron, J. B. and Gaines, R. R. (2020) 'The Burgess Shale paleocommunity with new insights from Marble Canyon, British Columbia', Paleobiology, 46(1), pp. 58-81. doi: 10.1017/pab.2019.42.

Nielsen, C. (1995) Animal Evolution: Interrelationships of the Living Phyla. Oxford: Oxford University Press.

O’Leary, M. A. and Kaufman, S. G. (2012) 'Morphobank 3.0: Web application for morphological phylogenetics and taxonomy’. Available at: http://www.morphobank.org.

Ortega-Hernández, J. (2016) 'Making sense of "lower" and "upper” stem-group Euarthropoda, with comments on the strict use of the name Arthropoda von Siebold, 1848', Biological Reviews, 91(1), pp. 255-273. doi: 10.1111/brv.12168.

Ortega-Hernández, J., Janssen, R. and Budd, G. E. (2017) 'Origin and evolution of the panarthropod head - A palaeobiological and developmental perspective', Arthropod Structure and Development, 46(3), pp. 354-379. doi: 10.1016/j.asd.2016.10.011.

Paradis, E. and Schliep, K. (2019) 'Ape 5.0: An environment for modern phylogenetics and evolutionary analyses in R', Bioinformatics, 35(3), pp. 526-528. doi:

10.1093/bioinformatics/bty633.

Park, T.-Y. S. et al. (2018) 'Brain and eyes of Kerygmachela reveal protocerebral ancestry of the panarthropod head', Nature Communications, 9(1), pp. 1-7. doi: 10.1038/s41467-018-03464-w.

Pates, S. et al. (2021) 'The diverse radiodont fauna from the Marjum Formation of Utah, USA (Cambrian: Drumian)', PeerJ, (e10509), pp. 1-43. doi: 10.7717/peerj.10509.

Pates, S. and Daley, A. C. (2019) 'The Kinzers Formation (Pennsylvania, USA): The most diverse assemblage of Cambrian Stage 4 radiodonts', Geological Magazine, 156(7), pp. 12331246. doi: 10.1017/S0016756818000547.

Rambaut, A. et al. (2018) 'Posterior summarization in Bayesian phylogenetics using Tracer 1.7', Systematic Biology, 67(5), pp. 901-904. doi: 10.1093/sysbio/syy032.

Robinson, D. F. and Foulds, L. R. (1981) 'Comparison of phylogenetic trees', Mathematical Biosciences, 53(1-2), pp. 131-147. doi: 10.1016/0025-5564(81)90043-2.

Robison, R. A., Babcock, L. E. and Gunther, V. G. (2015) Exceptional Cambrian Fossils From Utah: A Window Into The Age Of Trilobites. Salt Lake City: Utah Geological Survey.

Ronquist, F. et al. (2012) 'Mrbayes 3.2: Efficient Bayesian Phylogenetic Inference and Model Choice Across a Large Model Space', Systematic Biology, 61(3), pp. 539-542. doi: 10.1093/sysbio/sys029. 
Rueden, C. T. et al. (2017) 'ImageJ2: ImageJ for the next generation of scientific image data', BMC Bioinformatics, 18(1), pp. 1-26. doi: 10.1186/s12859-017-1934-z.

Sansom, R. S., Gabbott, S. E. and Purnell, M. A. (2010) 'Non-random decay of chordate characters causes bias in fossil interpretation', Nature, 463(7282), pp. 797-800. doi:

10.1038/nature08745.

Santos, J. C., de Almeida, W. R. and Fernandes, G. W. (2021) 'Arthropods: Why is it so crucial to know their biodiversity?', in Santos, J. C. and Fernandes, G. W. (eds) Measuring Arthropod Biodiversity. 1st edn. Springer, Cham, pp. 3-11. doi: https://doi.org/10.1007/978-3-030-53226-0.

Schliep, K. P. (2011) 'phangorn: Phylogenetic analysis in R', Bioinformatics, 27(4), pp. 592593. doi: 10.1093/bioinformatics/btq706.

Sheppard, K. A., Rival, D. E. and Caron, J.-B. (2018) 'On the Hydrodynamics of Anomalocaris Tail Fins', Integrative and Comparative Biology, 58(4), pp. 703-711. doi: 10.1093/icb/icy014.

St. John, K. (2017) 'Review paper: The shape of phylogenetic treespace', Systematic Biology, 66(1), pp. e83-e94. doi: 10.1093/sysbio/syw025.

Tarasov, S. (2019) 'Integration of Anatomy Ontologies and Evo-Devo Using Structured Markov Models Suggests a New Framework for Modeling Discrete Phenotypic Traits', Systematic Biology, 68(5), pp. 698-716. doi: 10.1093/sysbio/syz005.

Van Roy, P., Daley, A. C. and Briggs, D. E. G. (2015) 'Anomalocaridid trunk limb homology revealed by a giant filter-feeder with paired flaps', Nature, 522(7554), pp. 77-80. doi:

10.1038 /nature14256.

Vinther, J. et al. (2014) 'A suspension-feeding anomalocarid from the Early Cambrian', Nature, 507(7493), pp. 496-499. doi: 10.1038/nature13010.

Walcott, C. D. (1912) 'Middle Cambrian Branchiopoda, Malacostraca, Trilobita and Merostomata. Cambrian Geology and Paleontology II', Smithsonian Miscellaneous Collections, 57, pp. 145-228.

Watanabe, A. (2016) 'The impact of poor sampling of polymorphism on cladistic analysis', Cladistics, 32, pp. 317-334.

Whittington, H. B. (1975) 'The enigmatic animal Opabinia regalis, middle Cambrian, Burgess Shale, British Columbia', Philosophical Transactions of the Royal Society of London. B, Biological Sciences, 271(910), pp. 1-43. doi: 10.1098/rstb.1975.0033.

Whittington, H. B. and Briggs, D. E. G. (1985) 'The largest Cambrian animal, Anomalocaris, Burgess Shale, British Columbia', Philosophical Transactions of the Royal Society of London. B, Biological Sciences, 309(1141), pp. 569-609. doi: 10.1098/rstb.1985.0096.

Wolfe, J. M. and Hegna, T. A. (2014) 'Testing the phylogenetic position of Cambrian pancrustacean larval fossils by coding ontogenetic stages', Cladistics, 30(4), pp. 366-390. doi: 


\subsection{1/cla.12051.}

Wright, A. M. (2019) 'A Systematist's Guide to Estimating Bayesian Phylogenies From Morphological Data', Insect Systematics and Diversity, 3(3), pp. 1-14. doi: 10.1093/isd/ixz006.

Wright, A. M. and Lloyd, G. T. (2020) 'Bayesian analyses in phylogenetic palaeontology: interpreting the posterior sample', Palaeontology, 63(6), pp. 997-1006. doi: 10.1111/pala.12500.

Wright, A. M., Lloyd, G. T. and Hillis, D. M. (2016) 'Modeling character change heterogeneity in phylogenetic analyses of morphology through the use of priors', Systematic Biology, 65(4), pp. 602-611. doi: 10.1093/sysbio/syv122.

Yang, J. et al. (2015) 'A superarmored lobopodian from the Cambrian of China and early disparity in the evolution of Onychophora', Proceedings of the National Academy of Sciences of the United States of America, 112(28), pp. 8678-8683. doi: 10.1073/pnas.1505596112.

Yang, J. et al. (2016) 'Fuxianhuiid ventral nerve cord and early nervous system evolution in Panarthropoda', Proceedings of the National Academy of Sciences of the United States of America, 113(11), pp. 2988-2993. doi: 10.1073/pnas.1522434113.

Yang, J. et al. (2018) 'Early Cambrian fuxianhuiids from China reveal origin of the gnathobasic protopodite in euarthropods', Nature Communications, 9(1), pp. 1-9. doi: 10.1038/s41467-01702754-z.

Zeng, H. et al. (2020) 'An early Cambrian euarthropod with radiodont-like raptorial appendages', Nature, 588(7836), pp. 101-105. doi: 10.1038/s41586-020-2883-7.

Zhang, X. and Briggs, D. E. G. (2007) 'The nature and significance of the appendages of Opabinia from the Middle Cambrian Burgess Shale', Lethaia, 40(2), pp. 161-173. doi: 10.1111/j.1502-3931.2007.00013.x. 


\section{Extended Systematic Palaeontology}

\section{Family OPABINIIDAE Walcott, 1912}

Remarks. Walcott (1912) erected the Opabiniidae, a new family of anostracan crustaceans that included four genera: 'Bidentia', Leanchoilia, Opabinia, and Yohoia. 'Bidentia' is a junior synonym of Leanchoilia (Bruton and Whittington, 1983), which with Yohoia now belongs to the class Megacheira. Opabinia is therefore the only remaining representative of the family Opabiniidae. Hutchinson (1930) created a new anostracan suborder Palaeanostraca to group this family with the Rochdalidae and Yohoidae. None of the components of these families are regarded as related to anostracans anymore: Opabinia is considered a stem group euarthropod, Rochdalia is the nymph of an insect (Rolfe, 1967), Yohoia and 'Bidentia'/Leanchoilia are megacheirans (Hou and Bergström, 1997), and Branchipusites was reinterpreted as an arthropleurid (Guthörl, 1934). Accordingly, we regard the suborder Palaeanostraca as invalid. More recently, Collins (1996) placed Opabiniidae into a new class, Dinocarida, along with members of the order Radiodonta. This clade has been shown to be paraphyletic in several phylogenetic analyses (e.g. Daley et al., 2009; Van Roy, Daley and Briggs, 2015; Lerosey-Aubril and Pates, 2018).

The genus Opabinia originally included two species, Opabinia regalis (type species) and Opabinia? media. Hutchinson (1930) considered the latter species to be composed of juvenile of $O$. regalis, and therefore to represent a junior synonym of this species. By contrast, Simonetta (1970) and Whittington (1975) regarded Opabinia? media as an invalid taxon, the three specimens putatively used by Walcott (1912) to define this species being recognized as belonging to a different genus or considered too poorly preserved to be assigned to any known taxon. A poorly preserved fossil recovered from the Furongian of Siberia was later used to describe a new species, Opabinia norilica (Miroshnikov and Krawzov, 1960), but this was rejected by Whittington (1975). In summary, Opabinia is composed solely of the type species, Opabinia regalis.

In this study we find phylogenetic support for including a new taxon KUMIP 314087 in the family Opabiniidae, under both maximum parsimony and Bayesian inference methods. Morphological support for uniting these taxa comes from a shared proboscis (not well preserved in KUMIP 314087), dorsal intersegmental furrows in the trunk, and small lateral flaps. KUMIP 314087 and Opabinia regalis also both possess a tail fan with paired caudal rami, and setal structures which cover the anterior of the flap, though those of KUMIP 314087 also cover the entire dorsal surface. The presence of 15 flap-bearing trunk segments might also be common to the two taxa (though the exact number is only tentative in KUMIP 314087, and this character is not included in the phylogenetic analysis). Opabinia regalis has stalked eyes, but while eyes are identified in the head region of KUMIP 314087, there is no evidence that these structures are stalked.

Notably, while a presence of a proboscis, perhaps the most famous and unusual character observed in Opabinia regalis, is included in the diagnosis for the family, it may be possible to identify future opabiniids lacking this feature. The proboscis is known in Opabinia and 
tentatively in KUMIP 314087. Our phylogenetic analyses where a proboscis is coded as uncertain in KUMIP 314087 also return this taxon as sister group to Opabinia (Supplementary Fig. 3A, B, 4) and therefore as a member of Opabiniidae.

\section{Additional implications of our phylogenetic results}

Radiodonta paraphyly?. Using MP, Radiodonta is resolved as a monophyletic group, alongside a very small percentage of BI posterior trees (teal points in Supplementary Fig. 7). The majority of BI posterior trees, and therefore the majority of the treespace, support radiodont paraphyly (Supplementary Fig. 7).

When the trees are separated by what is sister to deuteropods, around half the space is occupied by trees supporting a monophyletic Deuteropoda + Amplectobeluidae + Anomalocarididae, however the clade Amplectobeluidae + Anomalocarididae can be either monophyletic or paraphyletic in this plot (Supplementary Fig. 5). When this area of the treespace is compared to what is occupied by monophyletic Amplectobeluidae + Anomalocarididae (Supplementary Fig. 7), there is only limited overlap in these two areas, lowering the support for the tree topology depicted in the consensus.

There is evidence that internal radiodont relationships are not confidently resolved based on the data (character matrix) and/or model of morphological character change. For example, trees where the family Hurdiidae is recovered as monophyletic are spread across the whole treespace, but at a low density. Often a tree with monophyletic Hurdiidae is very close in the treespace (i.e. with a low RF value or similar overall topology) to multiple trees where Hurdiidae is not resolved as a monophyletic group (Supplementary Fig. 7). Future work (ongoing) aimed at better resolving radiodont internal relationships, as well as improving model and matrix design to deal with this kind of problem common to palaeontological datasets will allow more certainty to be placed on the monophyly or paraphyly of radiodonts. Little weight should be placed on this particular result from this study, as the support for radiodont monophyly is poor and not enhanced by additional bipartitions (as in opabiniids), and as other matrices consistently resolve radiodonts as a monophyletic group when analysed with both MP and BI (e.g. Lerosey-Aubril and Pates, 2018; Moysiuk and Caron, 2019; Zeng et al., 2020). 


\section{References}

Bruton, D. L. and Whittington, H. B. (1983) 'Emeraldella and Leanchoilia, two arthropods from the Burgess Shale, Middle Cambrian, British Columbia', Philosophical Transactions of the Royal Society of London. B, Biological Sciences, 300(1102), pp. 553-582. doi: 10.1098/rstb.1983.0020.

Collins, D. (1996) 'The "evolution" of Anomalocaris and its classification in the arthropod class Dinocarida (nov.) and order Radiodonta (nov.)', Journal of Paleontology, 70(2), pp. 280-293. doi: $10.1017 / \mathrm{S} 0022336000023362$.

Daley, A. C. et al. (2009) 'The Burgess Shale Anomalocaridid Hurdia and Its Significance for Early Euarthropod Evolution', Science, 323(20 March), pp. 1597-1600.

Guthörl, P. (1934) 'Die Arthropoden aus dem Carbon und Perm des Saar-Nahe-Pfalz-Gebietes', Abhandlungen der Königlich preussischen geologischen Landesanstalt, 164, pp. 1-219.

Hou, X. and Bergström, J. (1997) 'Arthropods of the Lower Cambrian Chengjiang fauna, southwest China’, Fossils and Strata, 45(1), pp. 1-113.

Hutchinson, G. E. (1930) 'Restudy of some Burgess Shale fossils', Proceedings of the U.S. National Museum, 78(2661), pp. 1-24.

Lerosey-Aubril, R. and Pates, S. (2018) 'New suspension-feeding radiodont suggests evolution of microplanktivory in Cambrian macronekton', Nature Communications, 9(1), pp. 1-9. doi: 10.1038/s41467-018-06229-7.

Miroshnikov, L. D. and Krawzov, A. G. (1960) 'Rare paleontological remains and traces of life in late Cambrian deposits of the northwestern Siberian platform', Palaeontology and biostratigraphy of the Soviet Arctic, 3, pp. 28-41.

Moysiuk, J. and Caron, J.-B. (2019) 'A new hurdiid radiodont from the Burgess Shale evinces the exploitation of Cambrian infaunal food sources', Proceedings of the Royal Society B: Biological Sciences, 286(1908). doi: 10.1098/rspb.2019.1079.

Rolfe, W. D. I. (1967) 'Rochdalia, a Carboniferous insect nymph', Palaeontology, 10(2), pp. 307-313.

Simonetta, A. (1970) 'Studies on non trilobite arthropods of the Burgess Shale (Middle Cambrian). The genera Leanchoilia, Alalcomenaeus, Opabinia, Burgessia, Yohoia and Actaeus.', Palaeontographia Italia, 66, pp. 35-45.

Van Roy, P., Daley, A. C. and Briggs, D. E. G. (2015) 'Anomalocaridid trunk limb homology revealed by a giant filter-feeder with paired flaps', Nature, 522(7554), pp. 77-80. doi: 10.1038/nature14256. 
Walcott, C. D. (1912) 'Middle Cambrian Branchiopoda, Malacostraca, Trilobita and Merostomata. Cambrian Geology and Paleontology II', Smithsonian Miscellaneous Collections, 57, pp. $145-228$.

Whittington, H. B. (1975) 'The enigmatic animal Opabinia regalis, middle Cambrian, Burgess Shale, British Columbia', Philosophical Transactions of the Royal Society of London. B, Biological Sciences, 271(910), pp. 1-43. doi: 10.1098/rstb.1975.0033.

Zeng, H. et al. (2020) 'An early Cambrian euarthropod with radiodont-like raptorial appendages’, Nature, 588(7836), pp. 101-105. doi: 10.1038/s41586-020-2883-7. 


\section{Supplementary Figures}

a

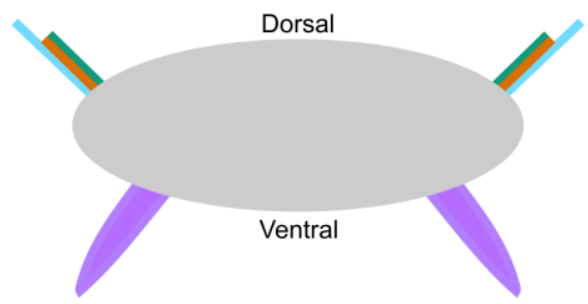

Anterior

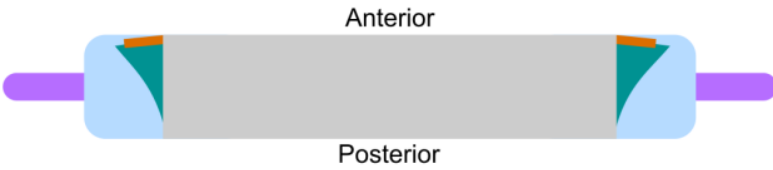

c

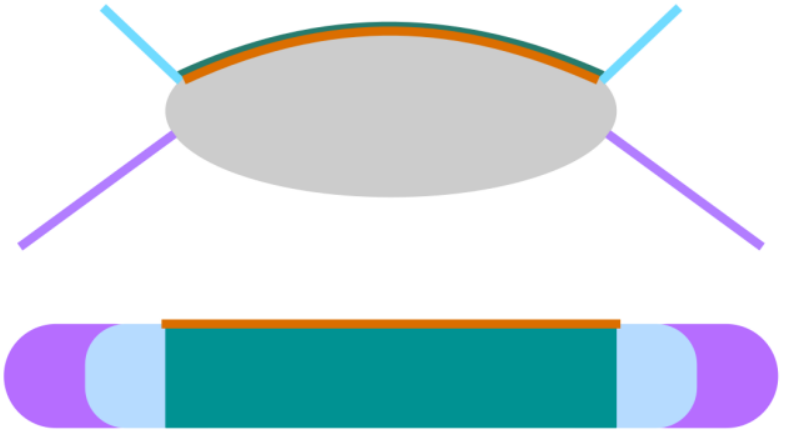

e

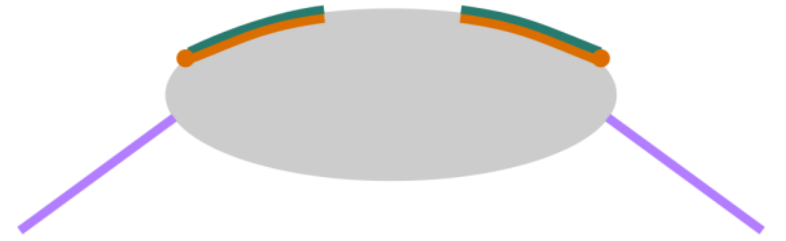

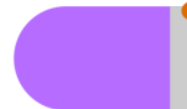
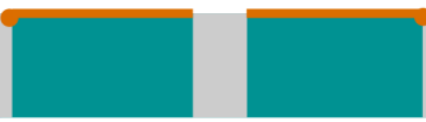

trunk segment

ventral limb/ endopod

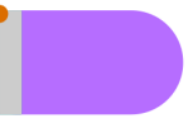

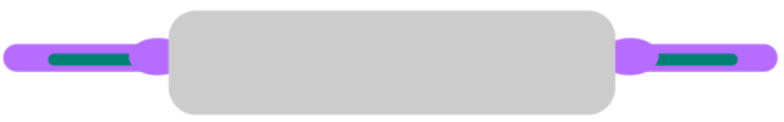

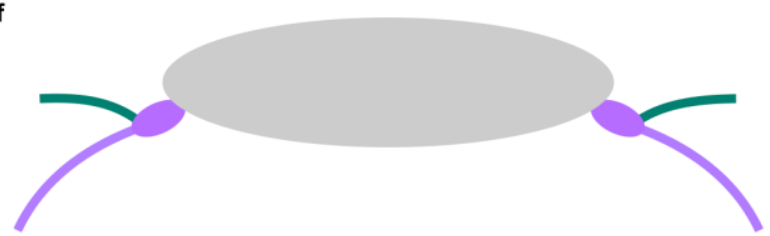

d
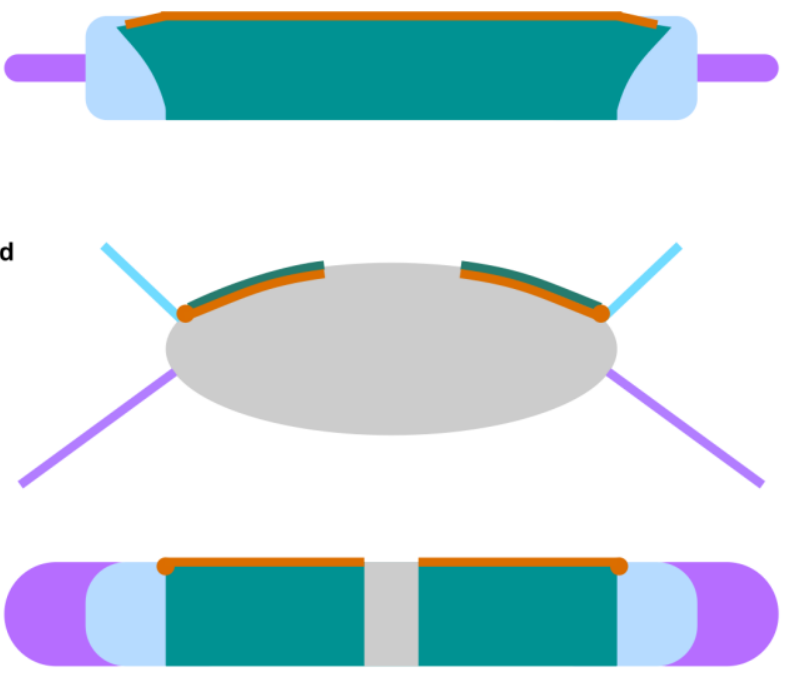

f
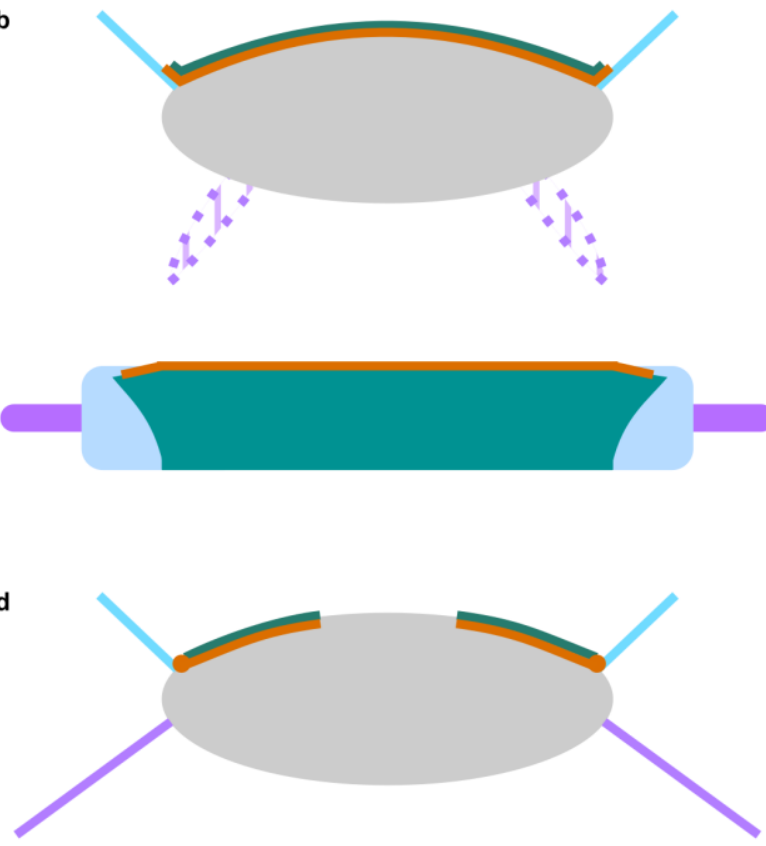

b

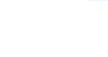

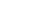




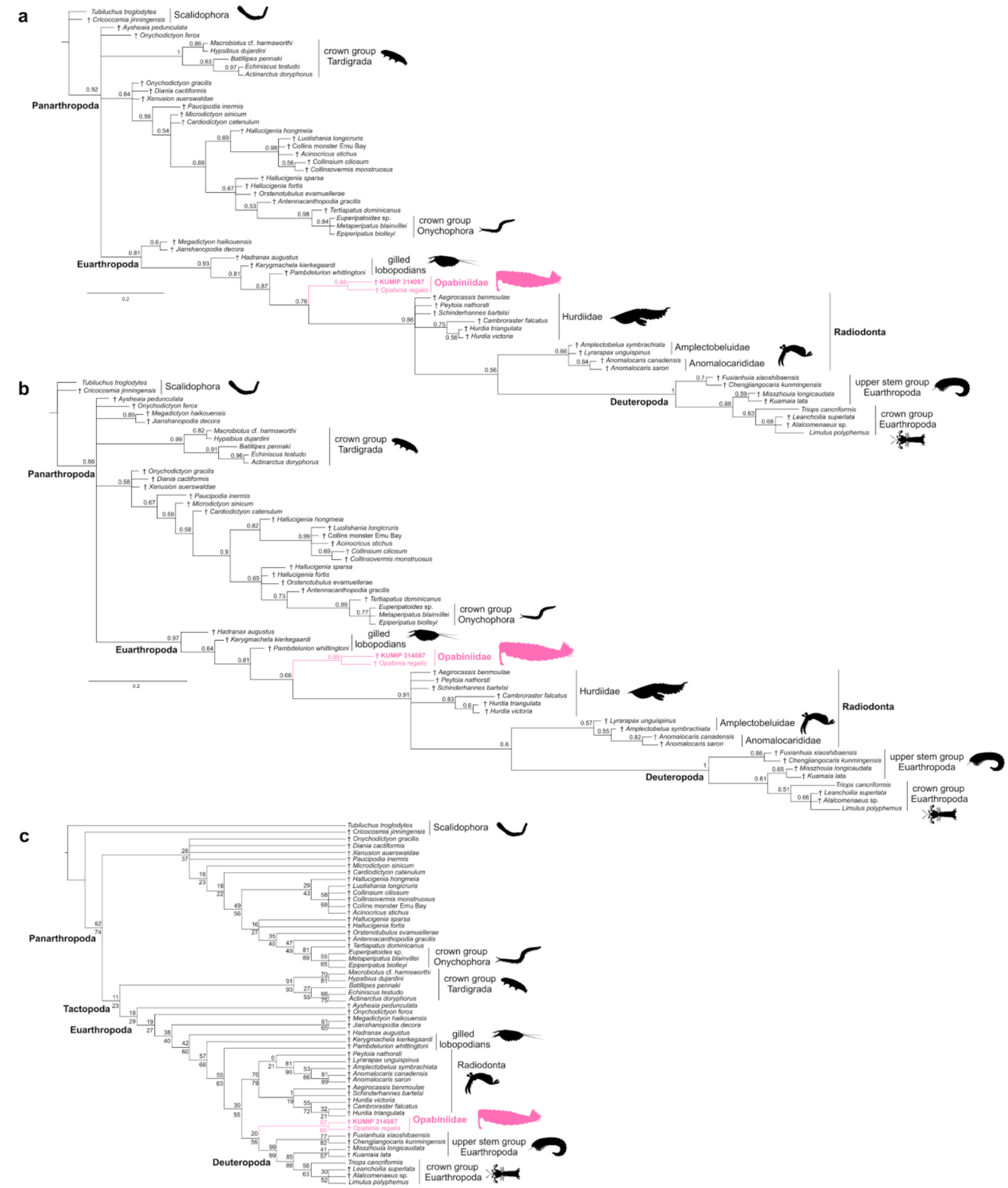

Supplementary Figure 2. Full phylogenetic results for opabiniids. (a) Majority rule consensus tree retrieved with BI, under minimize assumptions parameters. Numbers above nodes indicate posterior probabilities. (b) Majority rule consensus tree retrieved with BI, under maximize information parameters. Numbers above nodes indicate posterior probabilities. (c) Strict consensus tree retrieved with MP (12 MPTs, 230 steps, consistency index: 0.687, retention index: 0.889). Numbers above nodes indicate jackknife values; numbers below nodes indicate group present/contradicted (GC) values from symmetric resampling. 


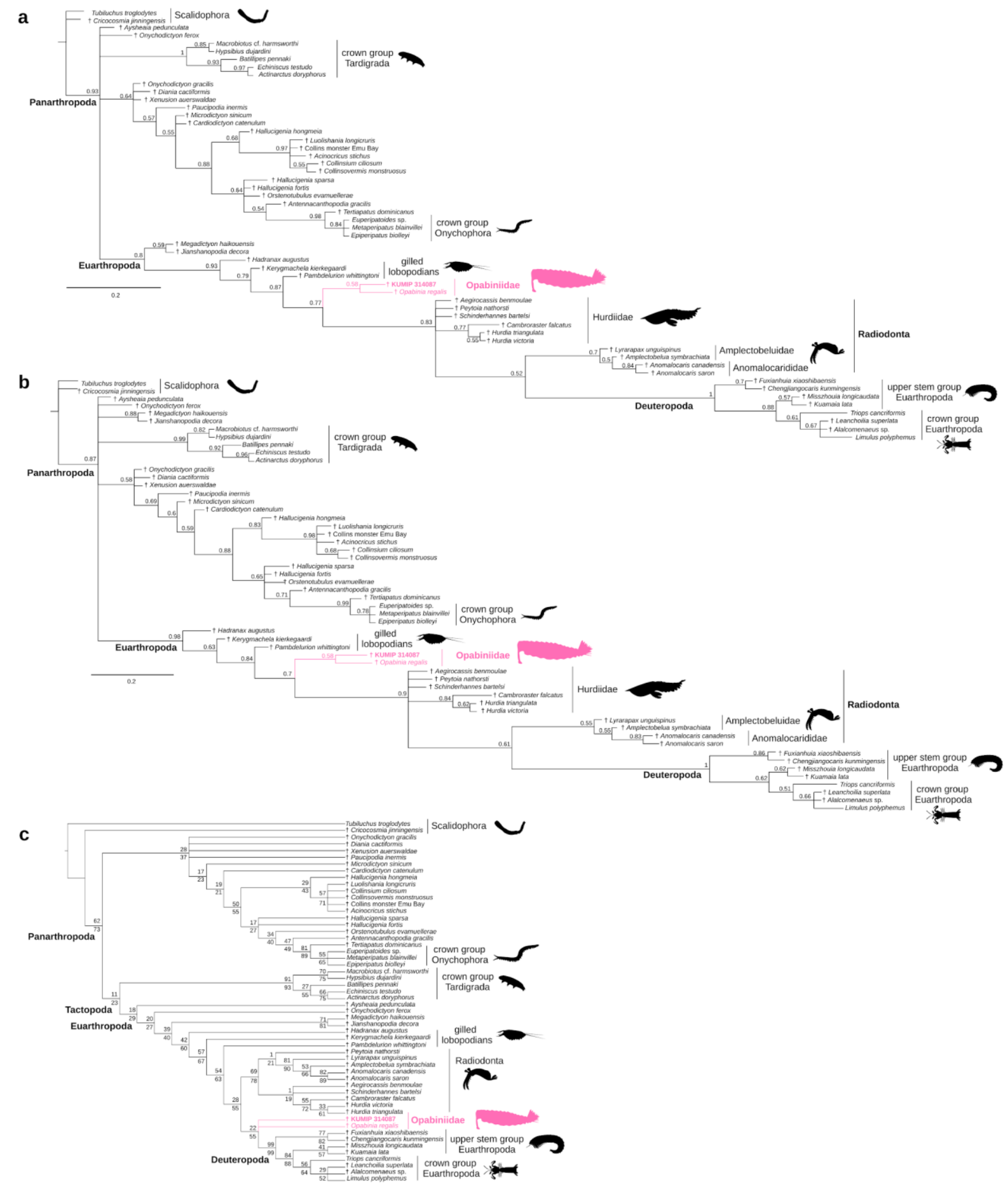

Supplementary Figure 3. Full phylogenetic results for opabiniids, where proboscis is coded as uncertain in KUMIP 314087. (a) Majority rule consensus tree retrieved with BI, under minimize assumptions parameters. Numbers above nodes indicate posterior probabilities. (b) Majority rule consensus tree retrieved with BI, under maximize information parameters. Numbers above nodes indicate posterior probabilities. (c) Strict consensus tree retrieved with MP (12 MPTs, 230 steps, consistency index: 0.687, retention index: 0.888). Numbers above nodes indicate jackknife values; numbers below nodes indicate $\mathrm{GC}$ values from symmetric resampling. 
bioRxiv preprint doi: https://doi.org/10.1101/2021.03.10.434726; this version posted March 11, 2021. The copyright holder for this preprint (which was not certified by peer review) is the author/funder, who has granted bioRxiv a license to display the preprint in perpetuity. It is made available under aCC-BY 4.0 International license.

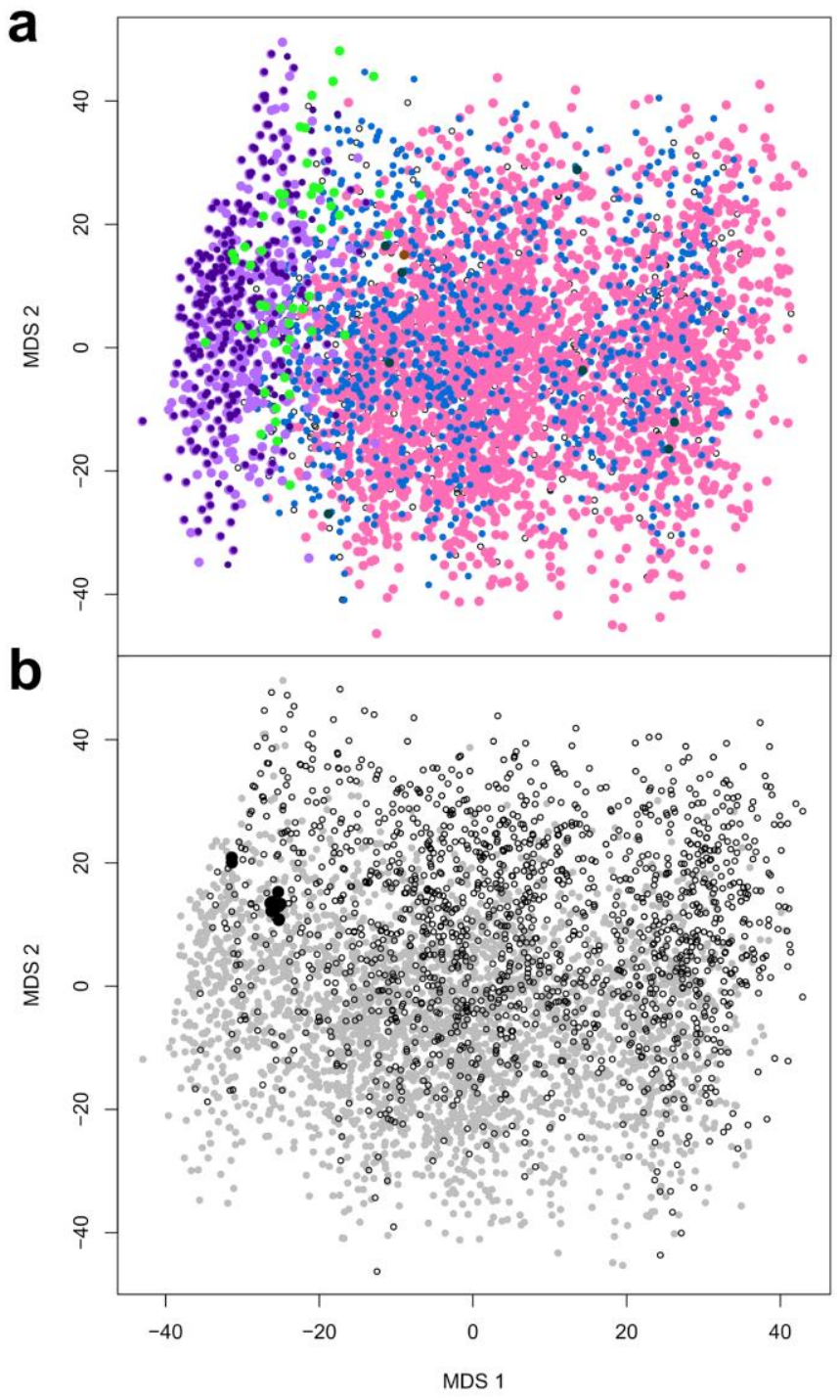

\begin{tabular}{|c|c|c|}
\hline \multicolumn{3}{|c|}{ KUMIP 314087 forms a clade with: } \\
\hline $\begin{array}{l}\text { Opabinia } \\
\text { Opabinia + } \\
\text { Deuteropoda }\end{array}$ & $\begin{array}{l}\text { Radiodonta + } \\
\text { Deuteropoda } \\
\text { Deuteropoda }\end{array}$ & $\begin{array}{l}\text { Radiodonta } \\
\text { Pambdelurion } \\
\text { Hurdiidae }\end{array}$ \\
\hline $\begin{array}{l}\text { BI: minimize } \\
\text { assumptions }\end{array}$ & $\begin{array}{l}\text { OBI: maximize } \\
\text { information }\end{array}$ & MPTs \\
\hline
\end{tabular}

Supplementary Figure 4. Treespace analysis for the modified matrix where KUMIP 314087 is recoded to reflect uncertainty in the presence of the proboscis. (a) Treespace plotted by bipartition resolving KUMIP 314087. Points are colored by relationships for this taxon. (b) Treespace plotted by analysis. 
bioRxiv preprint doi: https://doi org/10.1101/2021.0310.434726; this version posted March 11, 2021. The copyright holder for this preprint (which was not certified by peer review) is the author/funder, who has granted bioRxiv a license to display the preprint in perpetuity. It is made available under aCC-BY 4.0 International license.

\begin{tabular}{lcl}
\multicolumn{2}{c}{ total group Euarthropoda } & upper stem \& crown \\
\hline 'gilled lobopodians' & lower stem-group & 'Dinocarida'
\end{tabular}

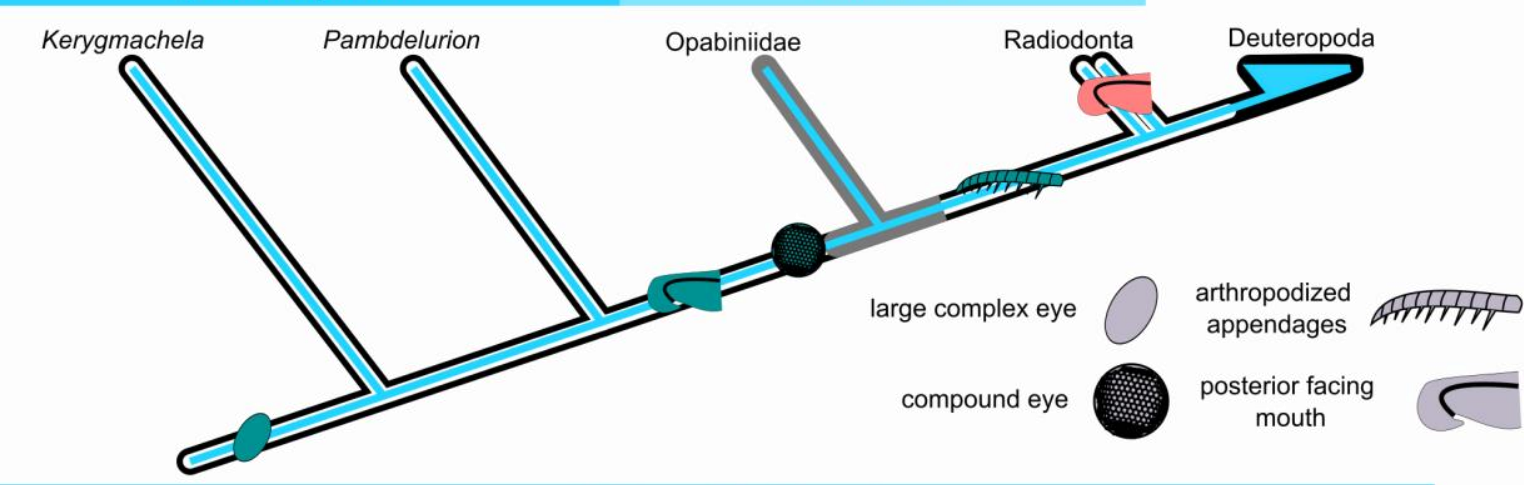

b
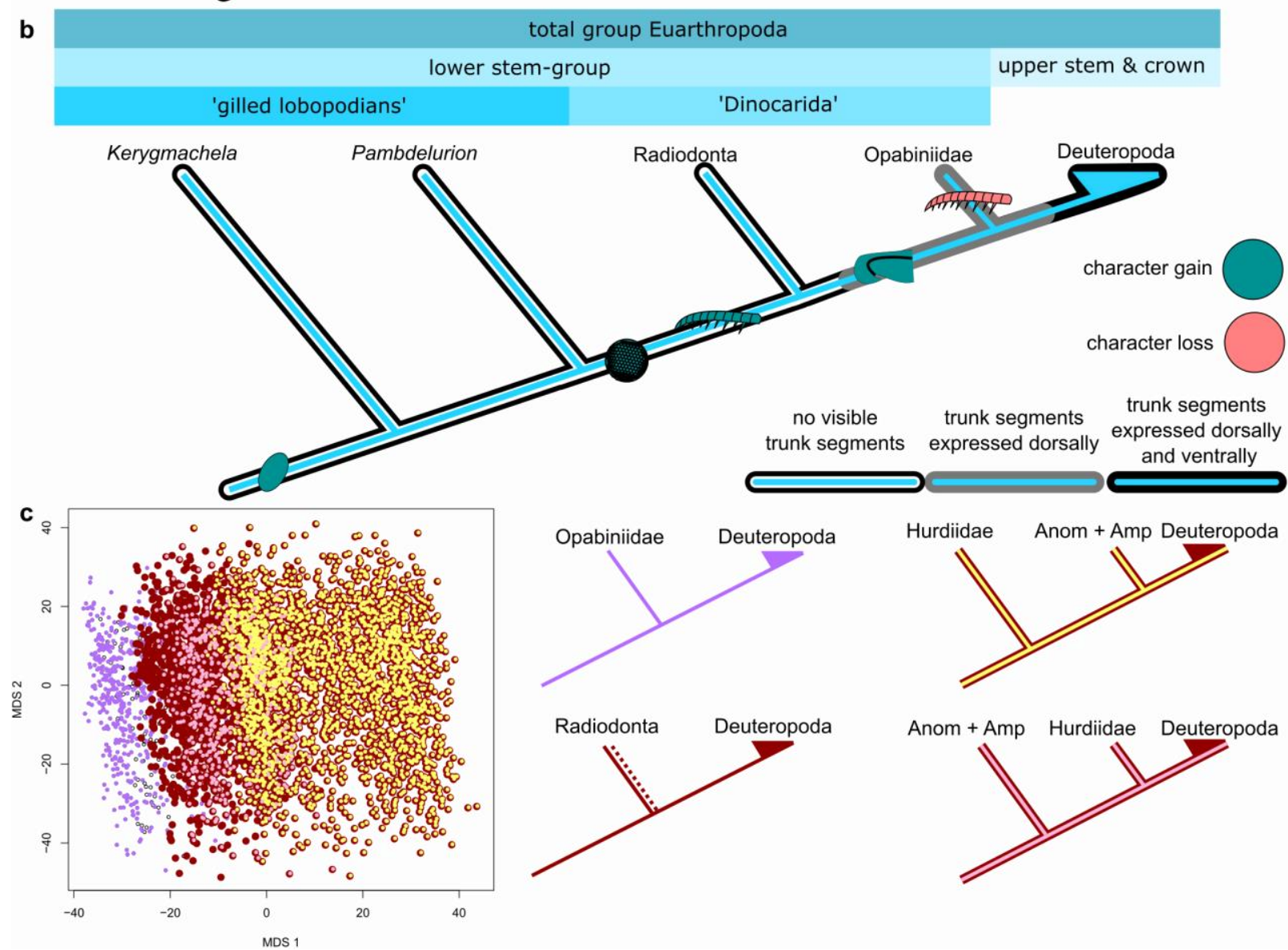

Supplementary Figure 5. Implications for evolution of head characters in the euarthropod stem group, based on our phylogenetic results, considering only evolutionary reversals. (a) Topology resulting from all BI consensus trees. (b) Topology resulting from MP consensus trees. (c) Treespace plotted by bipartition resolving the sister group of Deuteropoda. Points are colored by relationships for this taxon. 
bioRxiv preprint doi: https://doi.org/10.1101/2021.03.10.434726; this version posted March 11, 2021. The copyright holder for this preprint (which was not certified by peer review) is the author/funder, who has granted bioRxiv a license to display the preprint in perpetuity. It is made available under aCC-BY 4.0 International license.

a

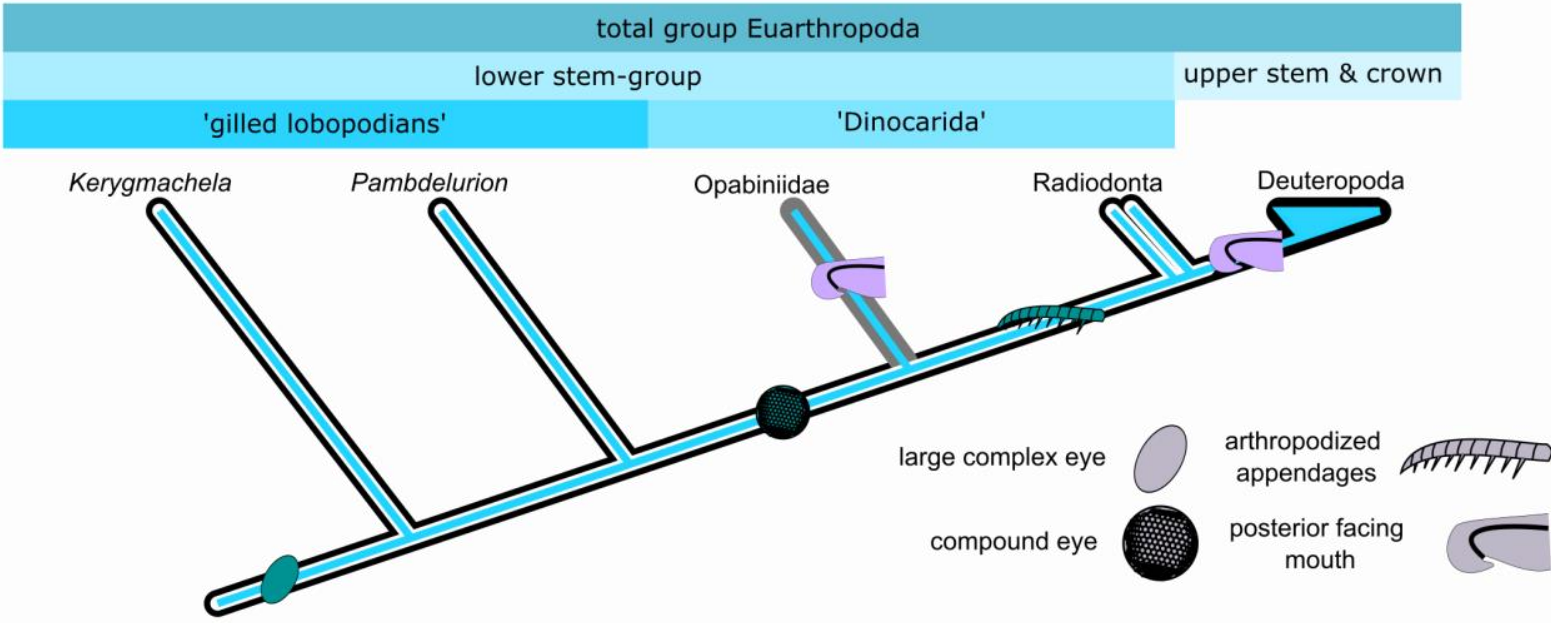

b

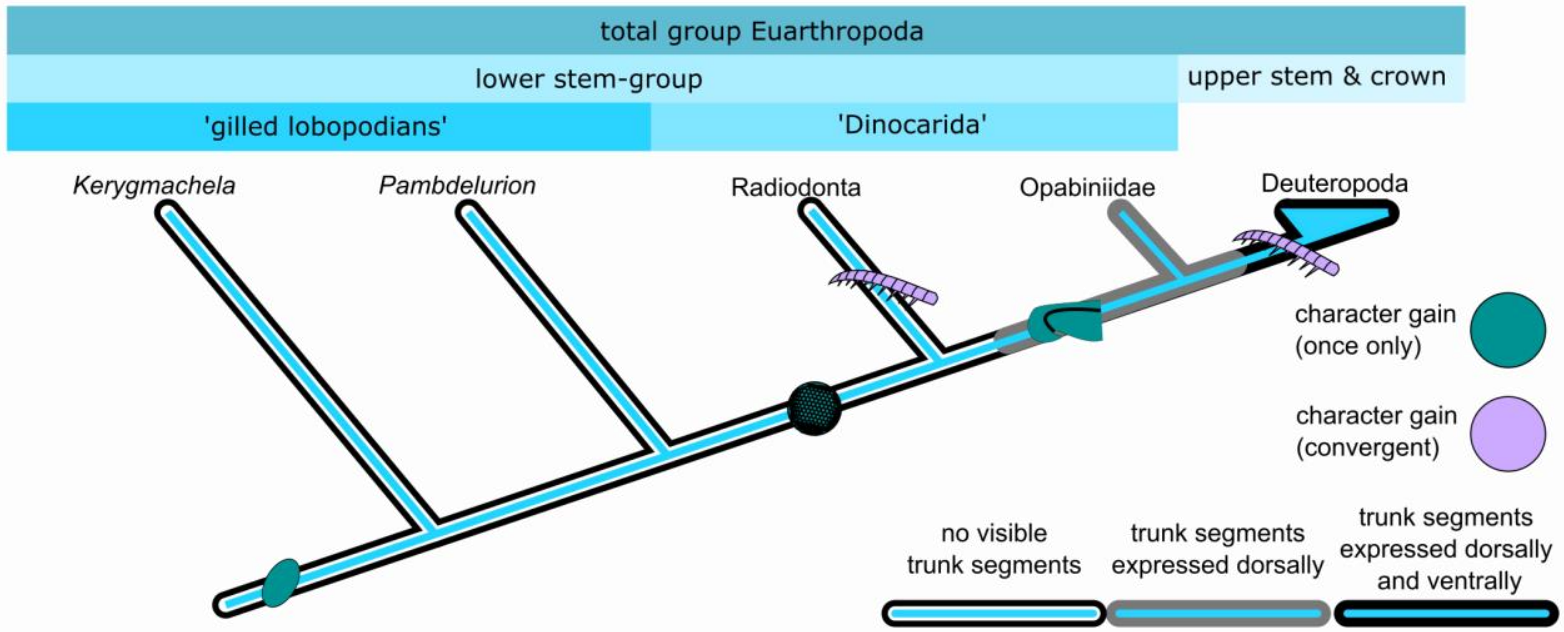

Supplementary Figure 6. Implications for evolution of head characters in the euarthropod stem group, based on our phylogenetic results, considering only evolutionary convergences. (a) Topology resulting from all BI consensus trees. (b) Topology resulting from MP consensus trees. 


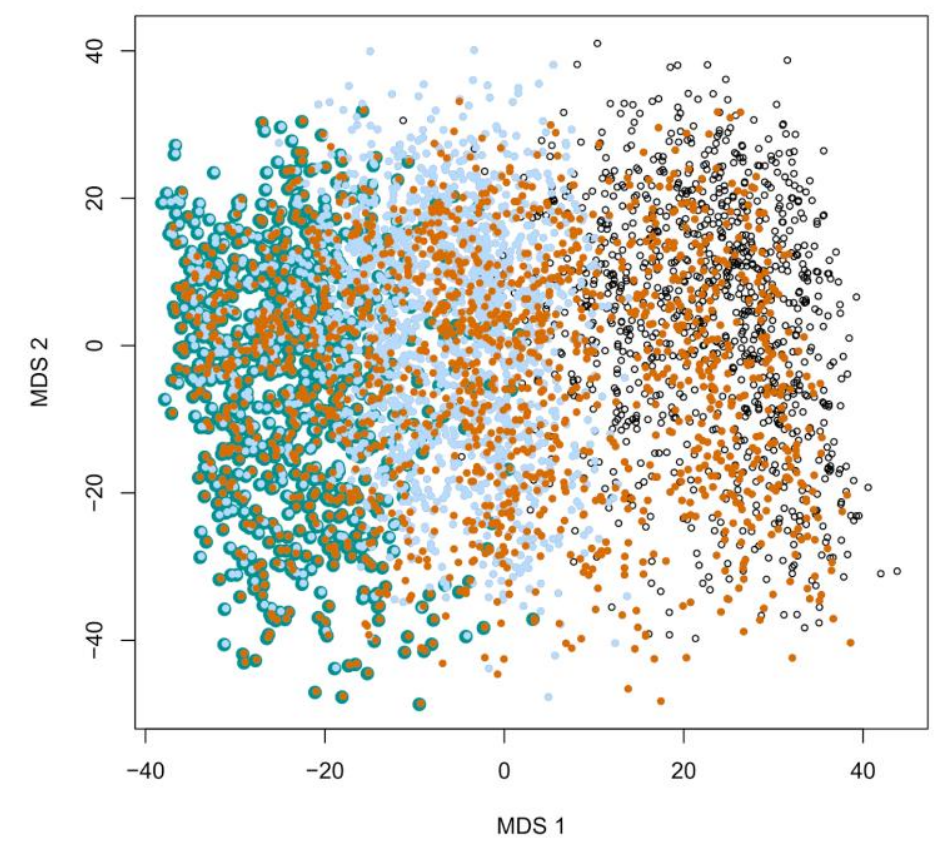

\begin{tabular}{|c|c|c|}
\hline \multicolumn{3}{|c|}{ Radiodont taxon that forms a clade: } \\
\hline Radiodonta & $\begin{array}{l}\text { Amplectobeluidae + } \\
\text { Anomalocarididae }\end{array}$ & Hurdiidae \\
\hline ONone & & \\
\hline
\end{tabular}

Supplementary Figure 7. Treespace plotted by bipartition resolving the monophyly of radiodont taxa. Points are colored by relationships for these selected taxa. 